\title{
Stabilized Phosphatidylinositol-5-Phosphate Analogues as Ligands for the Nuclear Protein ING2: Chemistry, Biology and Molecular Modeling
}

\author{
Wei Huang ${ }^{1}$, Honglu Zhang ${ }^{1}$, Foteini Davrazou ${ }^{2}$, Tatiana G. Kutateladze ${ }^{2}$, Xiaobing Shi $^{3}$, Or \\ Gozani $^{3}$, and Glenn D. Prestwich ${ }^{1}$ \\ 1 Department of Medicinal Chemistry, The University of Utah, 419 Wakara Way, Suite 205, Salt Lake City, \\ Utah 84108-1257 USA, Phone: +1-801-585-9051. Fax: +1-801-585-9053. Email: \\ gprestwich@pharm.utah.edu
}

2 Department of Pharmacology, University of Colorado Health Sciences Center, Aurora, Colorado 80045-0511 USA

3 Department of Biological Sciences, Stanford University, Palo Alto, California 94305 USA

\begin{abstract}
The interaction of PtdIns(5)P with the tumor suppressor protein ING2 has been implicated in the regulation of chromatin modification. To enhance the stability of PtdIns(5)P for studies of the biological role of in vivo, two phosphatase-resistant moieties were used to replace the labile 5phosphate. The total asymmetric synthesis of the 5-methylenephosphonate (MP) and 5phosphothionate (PT) analogues of PtdIns(5)P is described herein, and the resulting metabolicallystabilized lipid analogues were evaluated in three ways. First, liposomes containing either the dioleoyl MP or PT analogues bound to recombinant ING2 similar to liposomes containing dipalmitoyl PtdIns(5)P, indicating that the replacement of the hydrolyzable 5-phosphate group does not compromise the binding. Second, the dioleoyl MP and PT PtdIns(5)P analogues were equivalent to dipalmitoyl PtdIns(5)P in augmenting cell death induced by a DNA double-strand break in HT1080 cells. Finally, molecular modeling and docking of the MP or PT analogues to the C-terminus PtdInsPbinding region of ING2 (consisting of a PHD finger and a polybasic region) revealed a number of complementary surface and electrostatic contacts between the lipids and ING2.
\end{abstract}

\section{Introduction}

Phosphoinositide ( $\mathrm{PtdIns}_{\mathrm{n}}$ ) signaling involves a wide variety proteins that exhibit lipid recognition, kinase, phosphatase, or phospholipase activities. ${ }^{1,2}$ One relatively rare phosphoinositide, PtdIns(5)P, has been implicated as a critical regulator of nuclear signaling events in cell-cycle progression, ${ }^{3}$ for DNA damage-dependent ING2 association with chromatin, ${ }^{4}$ and to inhibit ATX1 gene expression programs. ${ }^{5}$ Still, relatively few details are understood with respect to the signaling functions of PtdIns(5)P due to the paucity of wellcharacterized nuclear PtdIns(5)P binding domains. The interaction discovered between PtdIns (5)P and ING2 (inhibitor of growth protein 2) was shown to require both a C-terminus plant homeodomain (PHD) zinc finger motif and a short stretch of polybasic residues ${ }^{6}$, and implicated ING2 as a potential nuclear target for PtdIns(5)P. 
The ING family of proteins is highly conserved from yeast to humans ${ }^{7}$ and different members are native subunits of histone acetyl transferase (HAT) and histone deacetylase (HDAC) complexes. ${ }^{8}$ Mammalian ING proteins are candidate tumor suppressor proteins, which cooperate with p53 to induce cellular growth arrest and apoptosis; for example, overexperession of ING2 stimulates acetylation of p53. 9,10 As a result, the ING family is alleged to link chromatin regulation with $\mathrm{p} 53$ function and tumor suppression. ING2 contains a PHD finger that recognizes tri-methylated at lysine 4 histone $\mathrm{H} 3$ tail. ${ }^{11,12}$ The ING2 PHD finger is also required for the interaction with $\operatorname{Ptd} \operatorname{Ins}(5) \mathrm{P},{ }^{6}$ and together with the 18 -residue polybasic region C-terminal to the PHD domain, is necessary and sufficient for phosphoinositide binding by ING2. ${ }^{13}$ Thus, a model of ING2 with both of PHD domain and polybasic region is required to understand the binding and physiological activities of PtdIns (5)P.

Although the crystal structure of the ING2 PHD domain has been determined ${ }^{12}$ and several homologous structures of ING proteins are available through the PDB bank, at present no 3D structure of ING2 that includes the flexible $\mathrm{C}$-terminal polybasic region is available. Thus, further characterization of the structure and function of the ING2-C-terminus will benefit from the use of modified PtdIns(5)P ligands.

In vivo studies of PtdIns(5)P are problematic because its rapid metabolism. Specifically, three important metabolic pathways are presently known to utilize PtdIns(5)P as a substrate. Two pathways involve kinases; $\operatorname{PtdIns}(4,5) \mathrm{P}_{2}$ is produced by the action of $\operatorname{PtdIns}(5) \mathrm{P}$ 4-kinase and PtdIns(3,5) $\mathrm{P}_{2}$ can be produced by PtdIns 3-kinase. ${ }^{2,14,15}$ The third route involves a ubiquitous cellular phosphatase activity that metabolizes PtdIns(5)P to PtdIns.

We have recently pursued a program to prepare metabolically-stabilized, e.g., phopholipaseand phosphatase-resistant analogues of the phosphoinositides PtdIns(3)P, ${ }^{16}, 17$ PtdIns(4,5) $\mathrm{P}_{2}, 18$ and PtdIns $(3,4,5) \mathrm{P}_{3} .{ }^{19}$ In these examples, as with analogues the phosphatase-labile lysophosphatidic acid (LPA), ${ }^{20}$ methyl phosphonates, fluoromethyl phosphosphonates, phosphorothionates and methylenephosphonates were used to replace the natural phosphomonoester or phosphodiester moieties. Herein we describe the total asymmetric synthesis of the 5-methylenephosphonate (MP) and 5-phosphothionate (PT) analogues of PtdIns(5)P (Figure 1) as water-soluble ligands with short dibutanoyl chains or as lipid-soluble amphiphiles with dioleoyl chains. We show that PtdIns(5)P analogues interact with the Cterminal region of ING2 using liposome binding assays. Further, cellular studies demonstrate that the MP and PT analogues are as bioactive as PtdIns(5)P in augmenting cell death induced by DNA damage. Finally, we construct 3D models of the ING2 polybasic region using homology modeling algorithms, and computationally dock the PtdIns(5)P analogues to these models.

\section{RESULTS AND DISCUSSION}

\section{Chemical Synthesis of Stabilized Phosphatidylinositol-5-Phosphate Analogues}

The syntheses of the metabolically-stabilized PtdIns(5)P analogues were based on modifications of routes to the corresponding PtdIns(3)P analogues. ${ }^{16,17}$ Each contained the following strategic steps: (a) selective protection of positions of inositol, ${ }^{21}$ in particular using the TBDPS group for the 1-position, benzoate group for 5-position, and MOM group for 2,3,4,6-positions; (b) introduction of the MP or PT functionality in protected form at the 5position; and (c) introduction of the diacylglycerol phosphate at the 1-position using phosphoramidite chemistry.

Scheme 1 illustrates the preparation of the 5-MP- PtdIns(5)P analogue. D-Camphor dimethyl acetal $^{22}$ gave exclusively the 2,3-bornanediyl-myo-inositol ${ }^{23}$, which was then regioselectively 
silylated at 1-OH with TBDPSCl. ${ }^{24}$ After reaction with benzoyl chloride and removal of bornanediyl group, the 5-benzoyl-1-TBDPS intermediate was isolated from the mixture containing 4-benzoate and 4,5-bisbenzoate products. All the remaining hydroxyl groups were protected as methoxymethyl (MOM) ethers to give intermediate 6. ${ }^{21}$ After removal of benzoate group with sodium methoxide, key intermediate 7 was obtained from myo-inositol in six steps.

Dimethyl phosphonomethyltriflate which is required for installation of methylenephosphonate to 5-position of 7, were prepared as described. ${ }^{25,26}$ The alkylation of 7 with dimethyl phosphonomethyltriflate was employed using NaH/THF in $86 \%$ yield. Use of $n$-BuLi 17,27 as the base in this reaction resulted more by-products and a lower yield. Then, the TBDPS group of 8 was removed with tetrabutylammonium fluoride trihydrate $\left(\mathrm{TBAF}_{-} 3 \mathrm{H}_{2} \mathrm{O}\right.$ ) at $\mathrm{rt}$ for 4 hours to give alcohol 9. Separately, the two diacylglyceryl phosphoramidites 10a and 10b were prepared from 1,2-O-isopropylidene-sn-glycerol in five steps as reported. ${ }^{17,28} \mathrm{Then}$, in the presence of $1 H$-tetrazole, 9 was treated with $10 \mathbf{a}$ (or $\mathbf{1 0 b}$ ), followed by oxidation with $t$ - $\mathrm{BuOOH}$ to give the fully protected intermediate 11a (or 11b). The cyanoethyl (CE) group was removed in the presence of triethylamine (TEA) and bis(trimethylsilyl)trifluoroacetamide (BSTFA), 29 and the phosphate methyl ester and MOM ether were removed using TMSBr and BSTFA. 21 After complete evaporation of organic solvent in vacuo, the crude product was treated with Dowex ion-exchange resin ${ }^{17}$ to yield the 5-MP analogues of PtdIns(5)P (1 and 2, Scheme 1).

To obtain the 5-PT analogues of PtdIns(5)P, we first attempted to use the protected 5phosphorothioate intermediate 13, prepared by phosphitylation of alcohol 7 with bis(2cyanoethyl)diisopropylphosphorodiamidite followed by oxidation with sulfur in $\mathrm{CS}_{2}$ /pyridine. The removal of TBDPS group of obtained product 12 was achieved by using HF-pyridine complex (Scheme 2) instead of TBAF because cyanoethyl group was labile to cleavage by TBAF. ${ }^{17}$ However, the long reaction time (3 weeks) proved to be a significant disadvantage of this method. We thus abandoned this intermediate and solved the problem by replacing the TBDPS group with triethylsilyl (TES) group ${ }^{19}$ as illustrated in Scheme 3.

Scheme 3 shows the preparation of the 5-PT analogues PtdIns(5)P. Thus, 5-benzoyl-1TBDPS-2,3,4,6-tetrakis(MOM)-inositol (6) was treated with TBAF to remove the 1-TBDPS ether; this was then replaced with TES ether by using TESCl. Although two additional steps were required, this change of protecting groups improves overall yield and reduces side products as found for a 3-PT analogue of $\operatorname{PtdIns}(3,4,5) \mathrm{P}_{3} \cdot{ }^{19}$ After debenzoylation of 14 with diisobutyl aluminium hydride (DIBAL-H), the phosphorothioate group was introduced in the 5-position as shown in Scheme 2. Deprotection of the TES group of $\mathbf{1 6}$ with $\mathrm{NH}_{4} \mathrm{~F}$ gave intermediate 13 efficiently and in high yield. Then, the diacylglycerophosphodiester linkage to the 1-position of $\mathbf{1 3}$ was created using either 10a (or 10b) and $1 \mathrm{H}$-tetrazole followed by oxidation. After deprotection of cyanoethyl group and MOM group, the final products of 5PT analogues of PtdIns(5)P (3 and 4$)$ were obtained.

\section{Liposome Binding Assay}

To determine the effect of the PtdIns(5)P head group modifications on the inositol ring recognition by ING2, PtdIns(5)P analogues were evaluated using liposome binding assays (Figure 2). The C-terminal region of ING2 (amino acids 200-280 of ING2) has been shown to interact with PtdIns(5)P in vitro and in vivo. ${ }^{6}$ In the absence of any phosphoinositide in the liposome composition or in the presence of unphosphorylated PtdIns, the GST-fused Cterminal region of ING2 (GST-ING2) remains primarily soluble. With the parent ligand dipalmitoyl PtdIns(5)P embedded in the liposome, GST-ING2 was strongly associated with the liposome fraction. Both modified lipids, 5-MP-PtdIns(5)P (2) and 5-PT PtdIns(5)P (4), bound GST-ING2 with nearly the same efficiency as the unmodified lipid, suggesting that these synthetic analogues could substitute for PtdIns(5)P in biochemical and biological assays. 


\section{HT1080 Cell Death Assay}

ING2 overexpression triggers a number of molecular events including p53 acetylation that can culminate in the induction of apoptosis; ${ }^{10}$ the lipid binding acitivity of ING2 is critical for these activities. ${ }^{6}$ Furthermore, endogenous generation of nuclear PtdIns(5)P is involved in cellular responses to genotoxic stress, through regulation of ING2 and likely a number of additional factors. ${ }^{30}$ To test whether the 5-PT and 5-MP analogues of PtdIns(5)P would retain the same function in this pathway, we measured the HT1080 cell death response to DNA damage following treatment with dipalmitoyl PtdIns(5)P and or with 5-MP-PtdIns(5)P (2) and 5-PT PtdIns(5)P (4) (Figure 3). PtdIns(5)P shows a statistically significant, albeit small, enhancement in the level of cell death induced by neocarzinostatin (NCS) treatment alone in HT1080 cells. Both the 5-MP-PtdIns(5)P analogue 2 and 5-PT PtdIns(5)P analogue 4 show an equivalent effect in promoting cell death. These results demonstrate a biological effect of the metabolically-stabilized PtdIns(5)P analogues in this nuclear stress response pathway.

\section{Molecular Modeling}

Combining known biochemical, structural and functional data on the ING2 PHD domain and polybasic region activities, we sought to model the C-terminal tail of ING2 to gain insights into its interactions with PtdIns(5)P analogues. However, little is known concerning the 3D structure of the last 18 residues, which is likely to be a random coil. To further characterize the structure of this region, we built twenty homology models of the ING2 C-terminus (residue 202-281 by employing MODELLER, ${ }^{31-33}$ a set of algorithms for homology modeling. Each computed model contained the conserved PHD domain and different polybasic regions based on reported crystal structures. These models included multiple possible stereochemical geometries for the polybasic tail as anticipated for simulation of a random coil. Next, we employed AutoDock 3.0.5 $34-36$ to dock the ligands to ING2 models successively and performed LIGPLOT 4.4.2 37 into study the preferred binding conformation and association within the ING2-PtdIns(5)P complex.

The sequence of human ING2 38 (202-281) was provided as input data, and five template structures with good sequence identities by SWISS-MODEL server (Figure 4A). ${ }^{39-41}$ They are solution structures of ING family proteins in PDB bank (http://www.rcsb.org/); ${ }^{42}$ 1wes, 1weu and 1wen are PHD domain of ING1-like protein; 2q6g is PHD domain of ING2; 1x4i is C-terminal of ING3 which contains twenty models extending beyond PHD domain, and these models provide the diverse templates for the $\mathrm{C}$-terminal tail. After sequence alignment by MODELLER, the automodel mode of MODELLER was used, based on each $1 \times 4 \mathbf{i}$ model and the other templates, thus affording twenty primary ING2 structures. Then, after side chain modeling and energy minimization for each structure an ensemble of the twenty homology models of the ING2 C-terminus were obtained. As shown in Figure 4B and 4C, these models contain a highly conserved PHD domain which end with a short helix (normally from Pro257 to Lys265), followed by a highly divergent set of orientations for the remainder of the polybasic region.

The polybasic region contains three arginine and five lysine residues that can form a binding pocket for the phosphoinositide. First, we studied the 3D structure of each model and observed the key features of each one. The helix C-terminal from the PHD domain (Pro257 to Lys265) showed good identity for the majority of models, and the side chain of Lys265 was close to the region of Tyr255 and Lys253 within PHD domain (Figures 5A and 5B). However, the polybasic tails were widely divergent in the absence of a phosphoinositide ligand. For example, in model 1 (Figure 5A), the end residues ( $\operatorname{Arg} 281, \operatorname{Arg} 279$, Arg278) move to $25 \AA$ away from the PHD domain (Arg278 to Lys253), such that the Arg and Lys residues in polybasic tail could not form an effective pocket. In contrast, in model 2 (Figure 5B), the tail loops back towards the PHD domain (Tyr255, Lys253) with proper torsion angles (9 ̊ from Arg278 to Lys253), 
forming a more reasonable binding pocket. Indeed, Arg279, Arg278 and Lys276 form a proper site with Lys265 and PHD domain contributing to the pocket. In this case, Lys265 is located in the site center and serves as a 'bridge' to connect the PHD domain and polybasic tail. Among the twenty models, six contained a pocket similar to that of model 2 . The other fourteen models had extended tails (as in model 1) but with widely divergent orientations.

Furthermore, we docked diC 4 -PtdIns(5)P to each of the twenty models using AutoDock3.0.5. The models containing a reasonable binding pocket that included the polybasic tail, helix and PHD domains provided better binding scores than other models. Supplemental Figures S1AS1D present the binding modes of $\mathrm{diC}_{4}$-PtdIns(5)P with models 2, 7, 9 and 10 which give the highest scores and most reasonable conformations. These models all gave similar binding modes with $\mathrm{diC}_{4}$-PtdIns(5)P. The inositol ring was located in the area of $\operatorname{Arg} 279, \operatorname{Arg} 278$, Asp277 and Lys265, and the phosphate and hydroxyl groups formed good hydrogen bond networks with these residues. The diacyl groups of lipid approached Tyr255 and Lys 253 of the PHD domain.

Finally, after overall examination on binding energy and structure rationality of these four models, we selected model 2 as ING2 C-terminal model to compare the binding features of $\operatorname{diC}_{18: 1}$-PtdIns(5)P with the corresponding metabolically-stabilized analogues. The binding conformations of $\mathrm{diC}_{18: 1}$-PtdIns(5)P, 5-MP-diC $18: 1$-PtdIns(5)P (2) and 5-PT-diC $18: 1$-PtdIns (5)P (4) are shown in Figure 6. These three compounds have similar conformations. The inositol ring is located in the pocket and one of acyl groups is oriented towards PHD domain (Tyr255, Lys253) and the other orients to another part of polybasic tail (Arg260, Lys273). The 5-phosphate of the inositol head group is located proximal to Arg278, while the 1-

phosphodiester linkage is pxoimal to Arg279 (Figure 6). These results indicated a good steric simulation of chemical geometry. We employed LIGPLOT4.4.2 to test the hydrogen bonds and hydrophobic contacts between ligands and ING2. Supplemental Figures S2-S4 show that the hydrogen bonds for the MP and PT analogues are almost identical with those for $\mathrm{diC}_{18: 1^{-}}$ PtdIns(5)P. However, there are more hydrophobic contacts observed for the longer acyl chains, thus enhancing interactions with the PHD domain. This can rationalize our observations (unpublished results) that the dioleoyl analogues showed higher affinity than the dibutanoyl analogues in each of the binding assay formats tested.

Finally, in agreement with the modeling studies, Lys 251, Lys 253, W254 and G261 residues of the PHD finger and the polybasic region of ING2 were perturbed in NMR spectra of the protein during gradual addition of inositol 1,5-bisphosphate $\left(\operatorname{Ins}(1,5) \mathrm{P}_{2}\right)$, the head group of PtdIns(5)P (Supplementary Figure S5 and S6). Supplementary Figure S5 shows normalized backbone amide chemical shift changes in $0.2 \mathrm{mM}$ ING2 induced by $24 \mathrm{mM} \operatorname{Ins}(1,5) \mathrm{P}_{2}$, while Supplementary Figure $S 6$ plots chemical shift changes vs. Ins $(1,5) \mathrm{P}_{2}$ concentration from $2 \mathrm{mM}$ to $24 \mathrm{mM}$. Thus, both of the predicted basic interaction regions of ING2 are involved in the coordination of the inositol head group.

In conclusion, the phosphatase-resistant PtdIns(5)P analogues should provide useful tools for further in vivo research on several physiologically important pathways, including those governed by ING2. The molecular modeling presented herein provides the first model of the full ING2 C-terminus, and reveals the possible binding mode of PtdIns(5)P (and its analogues) with ING2. These interactions support the biological results, provide new 3D structural information, and offer testable structure-activity hypotheses for further studies on the physiology of PtdIns(5)P binding proteins. 


\section{EXPERIMENTAL METHODS}

\section{General Chemical Reagents and Methods}

Chemicals were purchased from Aldrich and Acros Chemical Corp. and used without prior purification. Solvents were reagent-grade and distilled before use: $\mathrm{CH}_{2} \mathrm{Cl}_{2}$ was distilled from $\mathrm{CaH}_{2}$, and THF was distilled from sodium wire. TLC used precoated silica gel aluminum sheets (EM Science silica gel $60 \mathrm{~F}_{254}$ ). Flash chromatography (FC) employed Whatman 230 400 mesh ASTM silica gel. NMR spectra were recorded on a Varian INOVA 400 at $400 \mathrm{MHz}$ $\left({ }^{1} \mathrm{H}\right), 101 \mathrm{MHz}\left({ }^{13} \mathrm{C}\right), 162 \mathrm{MHz}\left({ }^{31} \mathrm{P}\right)$ and $376 \mathrm{MHz}\left({ }^{19} \mathrm{~F}\right)$ at $25{ }^{\circ} \mathrm{C}$. Chemical shifts are reported in ppm with TMS as internal standard $\left(_{-}=0.00\right) ;{ }^{31} \mathrm{P}, 85 \% \mathrm{H}_{3} \mathrm{PO}_{4}\left({ }_{-}=0.00\right) ;{ }^{19} \mathrm{~F}, \mathrm{CFCl}_{3}($ $=0.00$ ). Low and high-resolution mass spectra were obtained on HP5971A MSD and Finnigan MAT95 double focusing mass spectrometer (MS) instruments, respectively.

\section{D-1-O-(tert-Butyldiphenylsilyl)-2,3,4,6-O-tetrakis(methoxymethylene)-myo-inositol (7)}

To a solution of 6 (440 mg, $0.63 \mathrm{mmol})$ in methanol $(5 \mathrm{~mL}$ ) was added sodium methoxide (4 $\mathrm{mL}, 25 \%$ solution in anhydrous methanol). The mixture was stirred at r.t. for $24 \mathrm{~h}$ then $10 \mathrm{~mL}$ of ethyl acetate was added and stirred for $20 \mathrm{~min}$. The organic layer was washed with water, dried over anhydrous sodium sulfate. After filtration and concentration, the subsequent chromatography on silica gel (acetone/hexanes, 1:3) afforded $7(330 \mathrm{mg}, 88 \%)$ as a pale yellow oil. ${ }^{1} \mathrm{H}$ NMR $\left(400 \mathrm{MHz}, \mathrm{CDCl}_{3}\right)$ _ $7.71(\mathrm{~m}, 4 \mathrm{H}), 7.41(\mathrm{~m}, 6 \mathrm{H}), 4.78(\mathrm{~m}, 2 \mathrm{H}), 4.74(\mathrm{~d}, J=6.0$ $\mathrm{Hz}, 1 \mathrm{H}), 4.67(\mathrm{~d}, J=6.0 \mathrm{~Hz}, 1 \mathrm{H}), 4.62(\mathrm{~d}, J=6.0 \mathrm{~Hz}, 1 \mathrm{H}), 4.52(\mathrm{~d}, J=6.0 \mathrm{~Hz}, 1 \mathrm{H}), 4.42(\mathrm{~d}$, $J=6.0 \mathrm{~Hz}, 1 \mathrm{H}), 4.39(\mathrm{~d}, J=6.0 \mathrm{~Hz}, 1 \mathrm{H}), 3.77(\mathrm{~m}, 3 \mathrm{H}), 3.57(\mathrm{~m}, 1 \mathrm{H}), 3.42(\mathrm{~s}, 3 \mathrm{H}), 3.35(\mathrm{~s}$, $3 \mathrm{H}), 3.31(\mathrm{~s}, 3 \mathrm{H}), 3.26(\mathrm{~m}, 2 \mathrm{H}), 3.23(\mathrm{~s}, 3 \mathrm{H}), 1.07(\mathrm{~m}, 9 \mathrm{H})$, . MALDI-HRMS [M + Na] ${ }^{+}$calcd. For $\mathrm{C}_{30} \mathrm{H}_{46} \mathrm{O}_{10} \mathrm{SiNa}, 617.2752$; found 617.2749.

\section{D-1-O-(tert-Butyldiphenylsilyl)-5-(dimethyl methylenephosphonate)-2,3,4,6-O-tetrakis (methoxymethylene)-myo-inositol (8)}

To a solution of $7(115 \mathrm{mg}, 0.19 \mathrm{mmol})$ in THF $(10 \mathrm{~mL})$ was added $\mathrm{NaH}(100 \mathrm{mg})$ at $0{ }^{\circ} \mathrm{C}$ and stirred for $20 \mathrm{~min}$. Then, dimethylphosphonomethyltriflate was added and the mixture was warmed to r.t. and stirred for $12 \mathrm{~h}$. Ethyl acetate was added and the organic layer was washed with water, dried over anhydrous sodium sulfate, concentrated and chromatographed on silica gel (acetone/hexanes, 1:1) giving product $8(120 \mathrm{mg}, 86 \%)$ as a colorless oil. ${ }^{1} \mathrm{H}$ NMR (400 $\left.\mathrm{MHz}, \mathrm{CDCl}_{3}\right)_{-} 7.70(\mathrm{~m}, 4 \mathrm{H}), 7.41(\mathrm{~m}, 6 \mathrm{H}), 5.02(\mathrm{~d}, J=6.4 \mathrm{~Hz}, 1 \mathrm{H}), 4.81(\mathrm{~m}, 3 \mathrm{H}), 4.55(\mathrm{~d}$, $J=6.4 \mathrm{~Hz}, 1 \mathrm{H}), 4.46(\mathrm{~d}, J=6.4 \mathrm{~Hz}, 1 \mathrm{H}), 4.39(\mathrm{~d}, J=6.4 \mathrm{~Hz}, 1 \mathrm{H}), 4.29(\mathrm{~m}, 1 \mathrm{H}), 4.18-4.12(\mathrm{~m}$, $2 \mathrm{H}), 4.01(\mathrm{t}, J=9.6 \mathrm{~Hz}, 1 \mathrm{H}), 3.85-3.74(\mathrm{~m}, 8 \mathrm{H}), 3.49(\mathrm{~s}, 3 \mathrm{H}), 3.38(\mathrm{~s}, 3 \mathrm{H}), 3.24(\mathrm{~s}, 3 \mathrm{H}), 3.20$ $(\mathrm{s}, 1 \mathrm{H}), 3.12(\mathrm{~s}, 3 \mathrm{H}), 3.08(\mathrm{~m}, 2 \mathrm{H}), 1.09(\mathrm{~s}, 9 \mathrm{H}) ;{ }^{13} \mathrm{C} \mathrm{NMR}\left(101 \mathrm{MHz}, \mathrm{CDCl}_{3}\right)$ _ 136.3, 136.1, 134.3, 133.0, 130.3, 130.0, 128.1, 127.9, 99.2, 98.6, 97.4, 95.2, 85.6, 85.5, 79.0, 77.8, 75.6, $75.8,74.1,67.4,65.8,57.0,56.6,55.8,55.6,53.1,53.0,27.4,19.3 ;{ }^{31} \mathrm{P}$ NMR $(162 \mathrm{MHz}$, $\left.\mathrm{CDCl}_{3}\right)_{2}$ 24.7. MALDI-HRMS $[\mathrm{M}+\mathrm{Na}]^{+}$calcd. for $\mathrm{C}_{33} \mathrm{H}_{53} \mathrm{O}_{13} \mathrm{SiPNa}$, 739.2885; found 739.2888 .

1D-5-(dimethyl methylenephosphonate)-2,3,4,6-O-tetrakis(methoxymethylene)-myo-inositol (9)

To a solution of $\mathbf{8}(125 \mathrm{mg}, 0.17 \mathrm{mmol})$ in THF $(5 \mathrm{~mL})$ was added TBAF_3 $\mathrm{H}_{2} \mathrm{O}(150 \mathrm{mg})$. Then, the mixture was stirred at r.t. for $4 \mathrm{~h}$. The solvent was evaporated off and the residue was chromatographied on silica gel (acetone/hexanes, 2:1) giving product $9(80 \mathrm{mg}, 96 \%)$ as a colorless oil. ${ }^{1} \mathrm{H}$ NMR $\left(400 \mathrm{MHz}, \mathrm{CDCl}_{3}\right) \_4.83-4.69(\mathrm{~m}, 8 \mathrm{H}), 4.16(\mathrm{~d}, J=10.0 \mathrm{~Hz}, 2 \mathrm{H})$, $4.05(\mathrm{~m}, 1 \mathrm{H}), 3.91(\mathrm{t}, J=9.2 \mathrm{~Hz}, 1 \mathrm{H}), 3.79(\mathrm{~d}, J=10.4 \mathrm{~Hz}, 6 \mathrm{H}), 3.70(\mathrm{t}, J=9.2 \mathrm{~Hz}, 1 \mathrm{H})$, 3.38-3.27 (m, 14H), $3.18(\mathrm{t}, J=9.2 \mathrm{~Hz}, 1 \mathrm{H}) ;{ }^{13} \mathrm{C}$ NMR $\left(101 \mathrm{MHz}, \mathrm{CDCl}_{3}\right)_{-} 98.8$, 98.6, 98.2, $96.4,85.7,85.5,83.3,77.8,77.6,76.3,71.0,67.7,66.0,56.6,56.3,55.9,53.1(\mathrm{~m}) ;{ }^{31} \mathrm{P}$ NMR 
$\left(162 \mathrm{MHz}, \mathrm{CDCl}_{3}\right)_{-}$24.4. MALDI-HRMS $[\mathrm{M}+\mathrm{Na}]^{+}$calcd. for $\mathrm{C}_{17} \mathrm{H}_{35} \mathrm{O}_{13} \mathrm{PNa}, 501.1708$; found 501.1712 .

\section{D-O-(1,2-Di-O-butanoyl-sn-(2S)-glycerol-3-O-(cyanoethyl)phospho)-5-(dimethyl methylenephosphonate)-2,3,4,6-O-tetrakis(methoxymethylene)-myo-inositol (11a)}

To a solution of $\mathbf{9}(40 \mathrm{mg}, 0.084 \mathrm{mmol})$ in dichloromethane $(2 \mathrm{~mL})$ was added $1 H$-tetrazole $(20 \mathrm{mg}$ ) and $\mathrm{N}, \mathrm{N}$-diisopropyl- $O$-(cyanoethyl)- $O$-(dibutanoyl-sn-(2S)-glycerol)phosphonamidite (10a, $100 \mathrm{mg}$ ) at r.t. under Ar. After stirred at r.t. for $24 \mathrm{~h}, t-\mathrm{BuOOH}(0.1$ $\mathrm{mL}$ ) was added for oxidation and stirred for $1 \mathrm{~h}$. The solution was diluted by $\mathrm{CH}_{2} \mathrm{Cl}_{2}(20 \mathrm{~mL})$ and washed with $10 \%$ sodium bisulfite then dried over anhydrous sodium sulfate. After filtration and concentration, the residue was chromatographied on silica gel (acetone/hexanes, 2:1 then 3:1) giving product 11a $(45 \mathrm{mg}, 65 \%)$ as a colorless oil. ${ }^{1} \mathrm{H}$ NMR $(400 \mathrm{MHz}$, $\left.\mathrm{CDCl}_{3}\right)_{-} 5.17(\mathrm{~m}, 1 \mathrm{H}), 4.74-4.58(\mathrm{~m}, 8 \mathrm{H}), 4.26-4.02(\mathrm{~m}, 10 \mathrm{H}), 3.89-3.80(\mathrm{~m}, 2 \mathrm{H}), 3.70(\mathrm{~d}$, $J=10.8 \mathrm{~Hz}, 6 \mathrm{H}), 3.39-3.27(\mathrm{~m}, 13 \mathrm{H}), 3.07(\mathrm{t}, J=9.2 \mathrm{~Hz}, 1 \mathrm{H}), 2.67(\mathrm{~m}, 2 \mathrm{H}), 2.20(\mathrm{~m}, 4 \mathrm{H})$, $1.52(\mathrm{~m}, 4 \mathrm{H}), 0.83(\mathrm{~m}, 6 \mathrm{H}) ;{ }^{13} \mathrm{C} \mathrm{NMR}\left(101 \mathrm{MHz}, \mathrm{CDCl}_{3}\right)$ _ 173.2, 172.8, 116.7, 98.8, 98.7, 98.6, 97.7, 96.2, 85.5, 85.4, 77.5, 76.7, 75.6, 75.5, 74.7, 69.4, 69.3, 67.6, 66.29, 66.28, 66.25, $66.24,66.0,62.56,62.55,62.52,62.51,61.6,56.8,56.7,56.6,56.0,55.9,53.1,53.0,36.1,35.9$, 19.8, 19.7, 18.4, 13.7, 13.6; ${ }^{31}$ P NMR $\left(162 \mathrm{MHz}, \mathrm{CDCl}_{3}\right) \_23.9,-1.09,-1.15$. MALDI-HRMS $[\mathrm{M}+\mathrm{Na}]^{+}$calcd. for $\mathrm{C}_{31} \mathrm{H}_{57} \mathrm{O}_{20} \mathrm{NP}_{2} \mathrm{Na}$, 848.2841; found 848.2849.

1D-O-(1,2-Di-O-oleoyl-sn-(2S)-glycerol-3- $O$-(cyanoethyl)phospho)-5-(dimethyl methylenephosphonate)-2,3,4,6-O-tetrakis(methoxymethylene)-myo-inositol (11b) was obtained from 9 and $\mathbf{1 0 b}$ as described for $\mathbf{1 1 a}$, yield $45 \% .{ }^{1} \mathrm{H}$ NMR $\left(400 \mathrm{MHz}, \mathrm{CDCl}_{3}\right) \_5.32$ $(\mathrm{m}, 4 \mathrm{H}), 5.25(\mathrm{~m}, 1 \mathrm{H}), 4.84-4.67(\mathrm{~m}, 8 \mathrm{H}), 4.35-4.08(\mathrm{~m}, 10 \mathrm{H}), 3.98-3.90(\mathrm{~m}, 2 \mathrm{H}), 3.70(\mathrm{dd}$, $J=2.8,10.8 \mathrm{~Hz}, 6 \mathrm{H}), 3.49(\mathrm{~d}, J=10.0 \mathrm{~Hz}, 1 \mathrm{H}), 3.44(\mathrm{~s}, 3 \mathrm{H}), 3.43(\mathrm{~s}, 3 \mathrm{H}), 3.39(\mathrm{~s}, 3 \mathrm{H}), 3.37$ (s, 3H), $3.17(\mathrm{dt}, J=2.8,9.2 \mathrm{~Hz}, 1 \mathrm{H}), 2.76(\mathrm{~m}, 2 \mathrm{H}), 2.31(\mathrm{~m}, 4 \mathrm{H}), 1.98(\mathrm{~m}, 8 \mathrm{H}), 1.58(\mathrm{~m}, 4 \mathrm{H})$, $1.28(\mathrm{~m}, 40 \mathrm{H}), 0.85(\mathrm{~m}, 6 \mathrm{H}) ;{ }^{13} \mathrm{C} \mathrm{NMR}\left(101 \mathrm{MHz}, \mathrm{CDCl}_{3}\right)$ _ 173.4, 173.0, 130.2, 129.9, 116.6, 98.9, 98.8, 98.7, 97.7, 96.2, 96.1, 85.5, 85.4, 77.2, 76.7, 75.6, 75.5, 74.7, 69.4, 69.3, 67.8, 66.3, 66.2, 66.1, 62.5, 62.4, 61.7, 56.9, 56.8, 56.7 56.1, 55.9, 55.8, 53.1, 53.0, 34.2, 34.1, 31.7, 29.97, $29.94,29.73,29.53,29.45,29.42,29.35,29.32,29.29,27.4,25.0,22.9,19.8,19.7,14.3 ;{ }^{31} \mathrm{P}$ NMR $\left(162 \mathrm{MHz}, \mathrm{CDCl}_{3}\right) \_24.0,-0.97,-0.99$. MALDI-HRMS $[\mathrm{M}+\mathrm{Na}]^{+}$calcd. for $\mathrm{C}_{59} \mathrm{H}_{109} \mathrm{O}_{20} \mathrm{NP}_{2} \mathrm{Na}, 1236.6910$; found 1236.6934.

\section{D-O-(1,2-Di-O-butanoyl-sn-(2S)-glycerol-3-phospho)-5-(methylenephosphonate)-myo- inositol (1)}

To a solution of 11a (18 mg, $0.021 \mathrm{mmol})$ in $\mathrm{MeCN}(1 \mathrm{~mL})$ was added triethylamine $(0.5 \mathrm{~mL})$ and bis(trimethylsilyl)trifluoroacetamide (BSTFA, $0.5 \mathrm{~mL}$ ) at r.t. under Ar. After stirred at r.t. for $24 \mathrm{~h}$, the solvent was removed completely in vacuum. The residue was dissolved in $\mathrm{CH}_{2} \mathrm{Cl}_{2}(1 \mathrm{~mL})$, added trimethylsilyl bromide (TMSBr, $\left.0.5 \mathrm{~mL}\right)$ and BSTFA $(0.5 \mathrm{~mL})$, then stirred at r.t. under Ar for $10 \mathrm{~h}$. After concentration, methanol $(1 \mathrm{~mL})$ was added and stirred for $1 \mathrm{~h}$. The solution was evaporated and treated with cation-exchange resin (Dowex 50W-X8, $400 \mathrm{mesh})$ to give $1(9 \mathrm{mg}, 75 \%) .{ }^{1} \mathrm{H}$ NMR $\left(400 \mathrm{MHz}, \mathrm{CD}_{3} \mathrm{OD}\right) \_5.24(\mathrm{~m}, 1 \mathrm{H}), 4.36(\mathrm{~m}, 1 \mathrm{H})$, $4.26(\mathrm{~m}, 1 \mathrm{H}), 4.14(\mathrm{~m}, 3 \mathrm{H}), 3.99(\mathrm{~m}, 1 \mathrm{H}), 3.80(\mathrm{~m}, 3 \mathrm{H}), 3.66(\mathrm{~m}, 1 \mathrm{H}), 3.39(\mathrm{t}, J=9.2 \mathrm{~Hz}, 1 \mathrm{H})$, $3.15(\mathrm{t}, J=9.2 \mathrm{~Hz}, 1 \mathrm{H}), 2.28(\mathrm{dd}, J=7.6,16.0 \mathrm{~Hz}, 4 \mathrm{H}), 1.58(\mathrm{p}, J=6.8 \mathrm{~Hz}, 4 \mathrm{H}), 0.89(\mathrm{q}, J=$ $6.8 \mathrm{~Hz}, 6 \mathrm{H}) ;{ }^{13} \mathrm{C}$ NMR $\left(101 \mathrm{MHz}, \mathrm{D}_{2} \mathrm{O}\right) \_$173.3, 172.9, 85.4, 85.3, 81.2, 77.9, 75.0, 74.6, 71.9, 71.6, 70.2, 68.2, 67.7, 66.3, 62.4, 61.5, 35.7, 35.6, 18.1, 12.9, 12.8; ${ }^{31} \mathrm{P}$ NMR $(162 \mathrm{MHz}$, $\left.\mathrm{D}_{2} \mathrm{O}\right)_{-}$19.3, $0.73(\mathrm{~m})$. MALDI-HRMS [M] $]^{+}$calcd. for $\mathrm{C}_{18} \mathrm{H}_{34} \mathrm{O}_{16} \mathrm{P}_{2}, 568.1322$; found 568.1299 .

1D- $O$-(1,2-Di- $O$-oleoyl-sn-(2S)-glycerol-3-phospho)-5-(methylenephosphonate)-myoinositol (2) was obtained from 11b as described for 1, yield 70\%. ${ }^{1} \mathrm{H}$ NMR (400 MHz, $\left.\mathrm{CD}_{3} \mathrm{OD}-\mathrm{CDCl}_{3}\right)_{-} 5.31(\mathrm{~m}, 5 \mathrm{H}), 4.19-4.07(\mathrm{~m}, 5 \mathrm{H}), 4.00(\mathrm{~m}, 2 \mathrm{H}), 3.93(\mathrm{t}, J=9.2 \mathrm{~Hz}, 1 \mathrm{H})$, 
$3.74(\mathrm{~m}, 2 \mathrm{H}), 3.39(\mathrm{~m}, 1 \mathrm{H}), 3.11(\mathrm{t}, J=9.2 \mathrm{~Hz}, 1 \mathrm{H}), 2.23(\mathrm{~m}, 4 \mathrm{H}), 2.01(\mathrm{~m}, 8 \mathrm{H}), 1.56(\mathrm{~m}, 4 \mathrm{H})$, $1.13(\mathrm{~m}, 40 \mathrm{H}), 0.87(\mathrm{t}, J=6.8 \mathrm{~Hz}, 6 \mathrm{H}) ;{ }^{13} \mathrm{C} \mathrm{NMR}\left(101 \mathrm{MHz}, \mathrm{CD}_{3} \mathrm{OD}-\mathrm{CDCl}_{3}\right) \_173.2,172.7$, $129.7,129.6,85.9,78.1,77.7,75.5,74.9,72.5,72.3,71.5,71.3,69.5,68.6,66.4,62.5,61.9$, $33.8,33.7,31.8,29.68,29.60,29.45,29.30,29.23,29.19,29.12,29.09,29.02,27.0,24.8,22.6$, 13.5, $13.4 ;{ }^{31} \mathrm{P}$ NMR $\left(162 \mathrm{MHz}, \mathrm{CD}_{3} \mathrm{OD}-\mathrm{CDCl}_{3}\right)$ _ 21.2, 0.68 (m). MALDI-HRMS [M $\mathrm{H}]^{-}$calcd. For $\mathrm{C}_{46} \mathrm{H}_{85} \mathrm{O}_{16} \mathrm{P}_{2}$, 955.5318; found 955.5345.

\section{D-1-O-(tert-Butyldiphenylsilyl)-5-(bis(cyanoethyl) phosphothionate)-2,3,4,6-O-tetrakis (methoxymethylene)-myo-inositol (12)}

To a solution of $7(100 \mathrm{mg}, 0.17 \mathrm{mmol})$ in acetonitrile $(5 \mathrm{~mL})$ was added $1 H$-tetrazole $(3 \%$ in $\mathrm{MeCN}, 0.09 \mathrm{~mL}, 0.39 \mathrm{mmol}$ ) and bis(2-cyanoethyl)diisopropylphosphorodiamidite (50 $\mathrm{mg}$, $0.185 \mathrm{mmol})$ at r.t. under Ar and stirred for $2 \mathrm{~h}$. Then, sulfur $(180 \mathrm{mg})$ and $\mathrm{CS}_{2} / \mathrm{Py}(1: 1,1.8$ $\mathrm{mL}$ ) was added and stirred at r.t. for $3 \mathrm{~h}$. After filtration, the filtrate was concentrated and chromatographied on silica gel (acetone/hexanes, 1:3) giving product $\mathbf{1 2}(100 \mathrm{mg}, 75 \%)$ as a colorless oil. ${ }^{1} \mathrm{H}$ NMR $\left(400 \mathrm{MHz}, \mathrm{CDCl}_{3}\right)$ - $7.70(\mathrm{~m}, 4 \mathrm{H}), 7.41(\mathrm{~m}, 6 \mathrm{H}), 4.94(\mathrm{~d}, J=6.0 \mathrm{~Hz}$, $1 \mathrm{H}), 4.88(\mathrm{~d}, J=6.0 \mathrm{~Hz}, 1 \mathrm{H}), 4.74(\mathrm{~m}, 2 \mathrm{H}), 4.57(\mathrm{~d}, J=6.4 \mathrm{~Hz}, 1 \mathrm{H}), 4.48(\mathrm{~d}, J=6.0 \mathrm{~Hz}, 1 \mathrm{H})$, 4.39-4.29 (m, 6H), $4.18(\mathrm{~d}, J=7.2 \mathrm{~Hz}, 1 \mathrm{H}), 4.07(\mathrm{~m}, 1 \mathrm{H}), 3.82(\mathrm{~m}, 2 \mathrm{H}), 3.49(\mathrm{~s}, 3 \mathrm{H}), 3.37(\mathrm{~s}$, $3 \mathrm{H}), 3.25(\mathrm{~s}, 3 \mathrm{H}), 3.22(\mathrm{~m}, 1 \mathrm{H}), 3.15(\mathrm{~m}, 1 \mathrm{H}), 3.10(\mathrm{~s}, 3 \mathrm{H}), 2.76(\mathrm{~m}, 4 \mathrm{H}), 1.09(\mathrm{~s}, 9 \mathrm{H}) ;{ }^{13} \mathrm{C}$ NMR $\left(101 \mathrm{MHz}, \mathrm{CDCl}_{3}\right)_{-}$136.2, 136.0, 134.1, 132.7, 130.4, 130.2, 128.2, 128.0, 117.0, 99.3, 98.6, 97.5, 95.4, 80.7, 80.6, 77.3, 76.6, 75.4, 75.2, 74.1, 62.84, 62.83, 62.78, 62.77, 57.3, 57.0, $55.9,55.7,27.5,19.5,19.4,19.3 ;{ }^{31} \mathrm{P}$ NMR $\left(162 \mathrm{MHz}, \mathrm{CDCl}_{3}\right)$ _ 69.1. MALDI-HRMS [M + $\mathrm{Na}]^{+}$calcd. for $\mathrm{C}_{36} \mathrm{H}_{53} \mathrm{~N}_{2} \mathrm{O}_{12} \mathrm{SSiPNa}$, 819.2718; found 819.2708.

1D-5-(bis(cyanoethyl) phosphothionate)-2,3,4,6-O-tetrakis(methoxymethylene)-myo-inositol (13)

Method A-A solution of $\mathbf{1 2}(100 \mathrm{mg}, 0.125 \mathrm{mmol})$ in THF $(5 \mathrm{~mL})$ was added hydrogen fluoride-pyridine complex $(70 \%, 0.6 \mathrm{~mL})$ at r.t. to a Teflon container. After sirred for 3 weeks, the solution was diluted with ethyl acetate and washed with $10 \% \mathrm{Na}_{2} \mathrm{CO}_{3}$. The organic layer was collected and dried over anhydrous sodium sulfate. After filtration, the filtrate was concentrated and chromatographied on silica gel (acetone/hexanes, 1:2) giving product 13 (50 $\mathrm{mg}, 71 \%)$ as a colorless oil.

Method B-To a solution of $\mathbf{1 6}(20 \mathrm{mg}, 0.030 \mathrm{mmol})$ in methanol $(0.5 \mathrm{~mL})$ was added ammonium fluoride $(20 \mathrm{mg})$ and stirred at r.t. for $20 \mathrm{~h}$. After removed the solvent, the residue was chromatographied on silica gel (acetone/hexanes, 1:2) to afford product 13 (15 mg, 90\%). ${ }^{1} \mathrm{H}$ NMR (400 MHz, $\left.\mathrm{CDCl}_{3}\right)$ _ 4.82-4.68 (m, 8H), 4.22-4.12 (m, 5H), $4.05(\mathrm{~s}, 1 \mathrm{H}), 3.94$ $(\mathrm{d}, J=7.2 \mathrm{~Hz}, 1 \mathrm{H}), 3.69(\mathrm{~d}, J=7.2 \mathrm{~Hz}, 1 \mathrm{H}), 3.49-3.34(\mathrm{~m}, 14 \mathrm{H}), 2.72(\mathrm{~m}, 4 \mathrm{H}) ;{ }^{13} \mathrm{C}$ NMR $(101$ $\left.\mathrm{MHz}, \mathrm{CDCl}_{3}\right)_{2} 116.9,98.8,98.7,98.1,96.5,82.2,81.3,76.8,76.7,76.3,70.7,62.85,62.84$, 62.77, 62.76, 57.0, 56.4, 56.0, 55.9, 19.6, $19.5 ;{ }^{31} \mathrm{P}$ NMR $\left(162 \mathrm{MHz}, \mathrm{CDCl}_{3}\right)$ _69.3. MALDIHRMS [M + Na] ${ }^{+}$calcd. for $\mathrm{C}_{20} \mathrm{H}_{35} \mathrm{~N}_{2} \mathrm{O}_{12} \mathrm{SPNa}$, 581.1541; found 581.1526 .

1D-1-O-(Triethylsilyl)-5-O-benzoxyl-2,3,4,6-O-tetrakis(methoxymethylene)-myo-inositol (14)

To a solution of 6 (400 mg, $0.57 \mathrm{mmol})$ in DMF $(5 \mathrm{~mL})$ was added TBAF_3 $\mathrm{H}_{2} \mathrm{O}(360 \mathrm{mg})$. The mixture was stirred at r.t. for $6 \mathrm{~h}$ then diluted with $30 \mathrm{~mL}$ of ethyl acetate. The solution was washed with $1 \mathrm{~N} \mathrm{HCl}$, water, then dried over anhydrous sodium sulfate. After filtration and concentration, the subsequent chromatography on silica gel (acetone/hexanes, 1:5) afforded pure product $(250 \mathrm{mg}, 95 \%)$ as a colorless oil. ${ }^{1} \mathrm{H}$ NMR $\left(400 \mathrm{MHz}, \mathrm{CDCl}_{3}\right)_{-} 8.11$ $(\mathrm{d}, J=6.8 \mathrm{~Hz}, 2 \mathrm{H}), 7.55(\mathrm{t}, J=7.2 \mathrm{~Hz}, 1 \mathrm{H}), 7.43(\mathrm{~m}, 2 \mathrm{H}), 5.27(\mathrm{t}, J=9.6 \mathrm{~Hz}, 1 \mathrm{H}), 4.87(\mathrm{~d}, J$ $=6.8 \mathrm{~Hz}, 1 \mathrm{H}), 4.82-4.68(\mathrm{~m}, 5 \mathrm{H}), 4.58(\mathrm{t}, J=6.8 \mathrm{~Hz}, 2 \mathrm{H}), 4.13(\mathrm{~m}, 2 \mathrm{H}), 3.87(\mathrm{t}, J=9.6 \mathrm{~Hz}$, $1 \mathrm{H}), 3.69(\mathrm{dd}, J=2.4,9.6 \mathrm{~Hz}, 1 \mathrm{H}), 3.61(\mathrm{~d}, J=9.6 \mathrm{~Hz}, 1 \mathrm{H}), 3.46(\mathrm{~s}, 3 \mathrm{H}), 3.39(\mathrm{~s}, 3 \mathrm{H}), 3.25$ (s, 3H), $3.02(\mathrm{~s}, 3 \mathrm{H}) ;{ }^{13} \mathrm{C}$ NMR (101 MHz, $\left.\mathrm{CDCl}_{3}\right)$ _ 166.0, 133.3, 130.3, 129.9, 128.6, 98.4, 
98.3, 98.1, 96.3, 81.2, 77.9, 76.9, 76.6, 74.0, 71.3, 56.2, 56.1, 56.0, 55.9. MALDI-HRMS [M $+\mathrm{Na}]^{+}$calcd. for $\mathrm{C}_{21} \mathrm{H}_{32} \mathrm{O}_{11} \mathrm{Na}, 483.1837$; found 483.1829. The obtained alcohol (150 mg, $0.33 \mathrm{mmol})$ was dissolved in $\mathrm{CH}_{2} \mathrm{Cl}_{2}(8 \mathrm{~mL})$ then imidazol $(100 \mathrm{mg}, 1.47 \mathrm{mmol})$ and triethylsilyl chloride $(0.15 \mathrm{~mL}, 0.89 \mathrm{mmol})$ was added. After the mixture was stirred at r.t. for $15 \mathrm{~h}$, it was washed with water and dried over anhydrous sodium sulfate. After filtration and concentration, the residue was chromatographied on silica gel (acetone/hexanes, 1:4) giving product $14(180 \mathrm{mg}, 96 \%)$ as a pale yellow oil. ${ }^{1} \mathrm{H} \mathrm{NMR}\left(400 \mathrm{MHz}, \mathrm{CDCl}_{3}\right)$ - $8.09(\mathrm{~m}, 2 \mathrm{H})$, $7.48(\mathrm{~m}, 1 \mathrm{H}), 7.35(\mathrm{~m}, 2 \mathrm{H}), 5.16(\mathrm{t}, J=9.6 \mathrm{~Hz}, 1 \mathrm{H}), 4.83(\mathrm{~d}, J=7.2 \mathrm{~Hz}, 1 \mathrm{H}), 4.74(\mathrm{~d}, J=7.2$ $\mathrm{Hz}, 1 \mathrm{H}), 4.71(\mathrm{~d}, J=7.2 \mathrm{~Hz}, 1 \mathrm{H}), 4.70(\mathrm{~d}, J=7.2 \mathrm{~Hz}, 1 \mathrm{H}), 4.66(\mathrm{~s}, 2 \mathrm{H}), 4.50$ (d, J = 7.2 Hz, $1 \mathrm{H}), 4.44(\mathrm{~d}, J=7.2 \mathrm{~Hz}, 1 \mathrm{H}), 4.06(\mathrm{t}, J=9.6 \mathrm{~Hz}, 1 \mathrm{H}), 3.94(\mathrm{~m}, 2 \mathrm{H}), 3.61(\mathrm{~m}, 2 \mathrm{H}), 3.36(\mathrm{~s}$, $3 \mathrm{H}), 3.35$ (s, 3H), 2.95 (s, 3H), $2.88(\mathrm{~s}, 3 \mathrm{H}), 0.90(\mathrm{~m}, 9 \mathrm{H}), 0.54(\mathrm{~m}, 6 \mathrm{H}) ;{ }^{13} \mathrm{C} \mathrm{NMR}(101 \mathrm{MHz}$, $\left.\mathrm{CDCl}_{3}\right)_{-}$166.2, 133.1, 133.0, 130.7, 129.9, 128.5, 98.3, 98.1, 97.2, 95.9, 82.9, 80.2 , 78.2, 76.9, 76.2, 73.9, 56.2, 56.1, 55.8, 55.7, 7.02, 5.04. MALDI-HRMS [M + Na $]^{+}$calcd. for $\mathrm{C}_{27} \mathrm{H}_{46} \mathrm{O}_{11} \mathrm{SiNa}, 597.2702$; found 597.2704.

\title{
1D-1-O-(Triethylsilyl)-2,3,4,6-O-tetrakis(methoxymethylene)-myo-inositol (15)
}

A solution of $14(180 \mathrm{mg}, 0.31 \mathrm{mmol})$ in $\mathrm{CH}_{2} \mathrm{Cl}_{2}(5 \mathrm{~mL})$ was cooled to $-78{ }^{\circ} \mathrm{C}$, then added diisobutyl aluminium hydride $(1.0 \mathrm{M}$ in hexane, $1.5 \mathrm{~mL}, 1.5 \mathrm{mmol})$. After the mixture was stirred at $-78{ }^{\circ} \mathrm{C}$ for $2 \mathrm{~h}$, methanol $(3 \mathrm{~mL})$ was added and stirred for $20 \mathrm{~min}$. The residue was warmed to r.t. and poured to wet sodium sulfate. After filtration and concentration, the subsequent chromatography on silica gel (acetone/hexanes, 1:10) afforded product 15 (120 $\mathrm{mg}, 82 \%)$ as a colorless oil. ${ }^{1} \mathrm{H}$ NMR $\left(400 \mathrm{MHz} \mathrm{CDCl}_{3}\right) \_4.84-4.70(\mathrm{~m}, 8 \mathrm{H}), 3.94(\mathrm{~s}, 1 \mathrm{H})$, $3.81(\mathrm{t}, J=9.6 \mathrm{~Hz}, 1 \mathrm{H}), 3.66(\mathrm{t}, J=9.6 \mathrm{~Hz}, 1 \mathrm{H}), 3.52-3.32(\mathrm{~m}, 15 \mathrm{H}), 0.94(\mathrm{t}, J=8.0 \mathrm{~Hz}, 9 \mathrm{H})$, $0.59(\mathrm{q}, J=8.0 \mathrm{~Hz}, 6 \mathrm{H}) ;{ }^{13} \mathrm{C} \mathrm{NMR}\left(101 \mathrm{MHz} \mathrm{CDCl}_{3}\right)$ _ 98.7, 98.4, 97.2, 96.0, 83.0, 80.7, 76.2, 75.4, 73.9, 72.8, 56.2, 56.1, 55.7, 55.6, 7.00, 5.05. MALDI-HRMS $[\mathrm{M}+\mathrm{Na}]^{+}$calcd. for $\mathrm{C}_{20} \mathrm{H}_{42} \mathrm{O}_{10} \mathrm{SiNa}$, 493.2445; found 493.2316.

\section{D-1-O-(Triethylsilyl)-5-(bis(cyanoethyl) phosphothionate)-2,3,4,6-O-tetrakis (methoxymethylene)-myo-inositol (16)}

\begin{abstract}
Bis(2-cyanethyl) diisopropyl-phosphorodiamidite (100 $\mathrm{mg}, 0.37 \mathrm{mmol}$ ) was added under an argon atmosphere to a solution of $15(40 \mathrm{mg}, 0.085 \mathrm{mmol})$ and $1 H$-tetrazole ( $3 \mathrm{wt} \%$ in MeCN, $1.2 \mathrm{~mL}, 0.52 \mathrm{mmol})$ in $\mathrm{MeCN}(2 \mathrm{~mL})$. After the mixture was stirred at r.t. for $6 \mathrm{~h}$, sulfur (72 $\mathrm{mg})$ and $\mathrm{CS}_{2} / \mathrm{Py}(1: 1,0.72 \mathrm{~mL})$ was added and stirred for $3 \mathrm{~h}$. The residue was filtered and the filtrate was concentrated. After subsequent chromatography on silica gel (acetone/hexanes, 1:4), product $16(45 \mathrm{mg}, 79 \%)$ was obtained as a colorless oil. ${ }^{1} \mathrm{H} \mathrm{NMR}\left(400 \mathrm{MHz}, \mathrm{CDCl}_{3}\right)_{-}$ 4.85-4.70 (m, 8H), $4.34(\mathrm{~m}, 5 \mathrm{H}), 3.95(\mathrm{~m}, 3 \mathrm{H}), 3.55(\mathrm{dd}, J=2.4,9.6 \mathrm{~Hz}, 1 \mathrm{H}), 3.48(\mathrm{dd}, J=$ 2,4, $9.6 \mathrm{~Hz}, 1 \mathrm{H}), 3.45(\mathrm{~s}, 3 \mathrm{H}), 3,44(\mathrm{~s}, 3 \mathrm{H}), 3,43(\mathrm{~s}, 3 \mathrm{H}), 3.41(\mathrm{~s}, 3 \mathrm{H}), 2.77(\mathrm{t}, J=6.0 \mathrm{~Hz}, 4 \mathrm{H})$, $0.97(\mathrm{t}, J=8.0 \mathrm{~Hz}, 9 \mathrm{H}), 0.62(\mathrm{q}, J=8.0 \mathrm{~Hz}, 6 \mathrm{H}) ;{ }^{13} \mathrm{C} \mathrm{NMR}\left(101 \mathrm{MHz}, \mathrm{CDCl}_{3}\right)$ _ 117.0, 98.7, 98.6, 97.2, 96.7, 81.0, 80.9, 76.9, 76.4, 76.2, 73.5, 62.8, 62.7, 57.1, 57.0, 56.0, 55.7, 19.5, 19.4, 7.04, 5.05; ${ }^{31} \mathrm{P}$ NMR (162 MHz, $\left.\mathrm{CDCl}_{3}\right)$ _ 69.1. MALDI-HRMS $[\mathrm{M}+\mathrm{Na}]^{+}$calcd. for $\mathrm{C}_{26} \mathrm{H}_{49} \mathrm{~N}_{2} \mathrm{O}_{12} \mathrm{PSSiNa}$, 695.2405; found 695.2392.
\end{abstract}

\section{D-1-O-(1,2-Di-O-butanoyl-sn-(2S)-glycerol-3-O-(cyanoethyl)phospho)-5-(bis(cyanoethyl) phosphothionate)-2,3,4,6-O-tetrakis(methoxymethylene)-myo-inositol (17a)}

To a solution of $13(25 \mathrm{mg}, 0.045 \mathrm{mmol})$ in dichloromethane $(2 \mathrm{~mL})$ was added $1 H$-tetrazole $(20 \mathrm{mg}$ ) and $\mathrm{N}, \mathrm{N}$-diisopropyl- $O$-(cyanoethyl)- $O$-(dibutanoyl-sn-(2S)-glycerol)phosphonamidite (10a, $75 \mathrm{mg})$ at r.t. under Ar. After stirred at r.t. for $24 \mathrm{~h}, t$-BuOOH $(0.1 \mathrm{~mL})$ was added for oxidation and stirred for $1 \mathrm{~h}$. The solution was diluted by $\mathrm{CH}_{2} \mathrm{Cl}_{2}(20 \mathrm{~mL})$ and washed with $10 \%$ sodium bisulfite then dried over anhydrous sodium sulfate. After subsequent chromatography on silica gel (acetone/hexanes, 1:1), product 17a (20 mg, 50\%) was obtained as a colorless oil. ${ }^{1} \mathrm{H}$ NMR $\left(400 \mathrm{MHz} \mathrm{CDCl}_{3}\right) \_5.22(\mathrm{~m}, 1 \mathrm{H}), 4.75-4.67(\mathrm{~m}, 8 \mathrm{H}), 4.30-4.08$ 
$(\mathrm{m}, 13 \mathrm{H}), 3.99(\mathrm{t}, J=9.6 \mathrm{~Hz}, 1 \mathrm{H}), 3.93(\mathrm{t}, J=9.6 \mathrm{~Hz}, 1 \mathrm{H}), 3.48(\mathrm{~d}, J=9.6 \mathrm{~Hz}, 1 \mathrm{H}), 3.39(\mathrm{~s}$, $3 \mathrm{H}), 3.37(\mathrm{~s}, 3 \mathrm{H}), 3.34(\mathrm{~s}, 3 \mathrm{H}), 3.33(\mathrm{~s}, 3 \mathrm{H}), 2.72(\mathrm{t}, J=6.0 \mathrm{~Hz}, 6 \mathrm{H}), 2.25(\mathrm{~m}, 4 \mathrm{H}), 1.59(\mathrm{~m}$, 4H), $0.89(\mathrm{~m}, 6 \mathrm{H}) ;{ }^{13} \mathrm{C} \mathrm{NMR}\left(101 \mathrm{MHz}, \mathrm{CDCl}_{3}\right) \_173.2,172.9,117.0,116.7,98.8,98.7,97.8$, 96.6, 80.6, 76.9, 76.1, 75.8, 74.7, 69.4, 66.3, 66.1, 63.1, 63.0, 62.7, 62.4, 61.6, 57.1, 57.0, 56.2, 55.9, 36.1, 36.0, 19.8, 19.6, 19.5, 18.4, 13.8, 13.7; ${ }^{31} \mathrm{P} \mathrm{NMR}\left(162 \mathrm{MHz}, \mathrm{CDCl}_{3}\right)_{2} 68.99,68.97$, $-1.25,-1.35$. MALDI-HRMS $[\mathrm{M}+\mathrm{Na}]^{+}$calcd. for $\mathrm{C}_{34} \mathrm{H}_{57} \mathrm{O}_{19} \mathrm{~N}_{3} \mathrm{P}_{2} \mathrm{SNa}$, 928.2674; found 928.2717 .

1D-1- $O$-(1,2-Di- $O$-oleoyl-sn-(2S)-glycerol-3- $O$-(cyanoethyl)phospho)-5-(bis (cyanoethyl) phosphothionate)-2,3,4,6-O-tetrakis(methoxymethylene)-myo-inositol (17b) was obtained from 13 and $\mathbf{1 0 b}$ as described for $\mathbf{1 7 a}$, yield $43 \%$. ${ }^{1} \mathrm{H}$ NMR $\left(400 \mathrm{MHz}, \mathrm{CDCl}_{3}\right) \_5.33(\mathrm{~m}, 4 \mathrm{H})$, $5.25(\mathrm{~m}, 1 \mathrm{H}), 4.74(\mathrm{~m}, 8 \mathrm{H}), 4.41-4.09(\mathrm{~m}, 13 \mathrm{H}), 4.04(\mathrm{t}, J=9.6 \mathrm{~Hz}, 1 \mathrm{H}), 3.96(\mathrm{t}, J=9.6 \mathrm{~Hz}$, $1 \mathrm{H}), 3.55(\mathrm{~d}, J=9.6 \mathrm{~Hz}, 1 \mathrm{H}), 3.43(\mathrm{~m}, 12 \mathrm{H}), 2.77(\mathrm{~m}, 6 \mathrm{H}), 2.32(\mathrm{~m}, 4 \mathrm{H}), 2.00(\mathrm{~m}, 8 \mathrm{H}), 1.59$ $(\mathrm{m}, 4 \mathrm{H}), 1.28(\mathrm{~m}, 40 \mathrm{H}), 0.87(\mathrm{~m}, 6 \mathrm{H}) ;{ }^{13} \mathrm{C} \mathrm{NMR}\left(101 \mathrm{MHz}, \mathrm{CDCl}_{3}\right)$ _ 173.4, 173.0, 130.2, 129.9, 117.0, 116.7, 98.8, 98.7, 97.8, 96.6, 80.6, 76.1, 75.9, 75.8, 74.7, 69.5, 66.3, 66.1, 63.0, 62.6, 62.4, 61.7, 57.2, 57.0 56.3, 56.0, 34.2, 34.1, 32.1, 29.97, 29.94, 29.73, 29.53, 29.41, 29.35, 29.30, 27.42, 27.39, 25.0, 22.9, 19.9, 19.8, 19.6, 19.5, 14.3; ${ }^{31} \mathrm{P}$ NMR $\left(162 \mathrm{MHz}, \mathrm{CDCl}_{3}\right)_{-}$ 69.01, 68.99, -1.15, -1.28. MALDI-HRMS $[\mathrm{M}+\mathrm{Na}]^{+}$calcd. for $\mathrm{C}_{62} \mathrm{H}_{109} \mathrm{O}_{19} \mathrm{~N}_{3} \mathrm{P}_{2} \mathrm{SNa}$, 1316.6743; found 1316.6707.

\section{D-O-(1,2-Di-O-butanoyl-sn-(2S)-glycerol-3-phospho)-5-(phosphothionate)-myo-inositol (3)}

To a solution of $17 \mathbf{a}(20 \mathrm{mg}, 0.022 \mathrm{mmol})$ in $\mathrm{MeCN}(1 \mathrm{~mL})$ was added triethylamine $(0.5 \mathrm{~mL})$ and bis(trimethylsilyl)trifluoroacetamide (BSTFA, $0.5 \mathrm{~mL}$ ) at r.t. under Ar. After stirred at r.t. for $24 \mathrm{~h}$, the solvent was removed completely in vacuum. The residue was dissolved in $\mathrm{CH}_{2} \mathrm{Cl}_{2}$ (1 mL), added trimethylsilyl bromide (TMSBr, $\left.0.5 \mathrm{~mL}\right)$ and BSTFA $(0.5 \mathrm{~mL})$, then stirred at r.t. under Ar for $2 \mathrm{~h}$. After concentration, methanol (1 mL) was added and stirred for $1 \mathrm{~h}$. The solution was evaporated and treated with cation-exchange resin (Dowex 50W-X8, $400 \mathrm{mesh})$ to give $3(8 \mathrm{mg}, 64 \%) .{ }^{1} \mathrm{H} \mathrm{NMR}\left(400 \mathrm{MHz}, \mathrm{D}_{2} \mathrm{O}\right) \_5.16(\mathrm{~m}, 1 \mathrm{H}), 4.28(\mathrm{dd}, J=3.2$, $12.8 \mathrm{~Hz}, 1 \mathrm{H}), 4.10(\mathrm{~m}, 2 \mathrm{H}), 3.94(\mathrm{~m}, 2 \mathrm{H}), 3.83(\mathrm{t}, J=9.6 \mathrm{~Hz}, 1 \mathrm{H}), 3.73(\mathrm{t}, J=9.6 \mathrm{~Hz}, 1 \mathrm{H})$, $3.65(\mathrm{t}, J=9.6 \mathrm{~Hz}, 1 \mathrm{H}), 3.45(\mathrm{~m}, 2 \mathrm{H}), 2.25(\mathrm{~m}, 4 \mathrm{H}), 1.45(\mathrm{~m}, 4 \mathrm{H}), 0.75(\mathrm{~m}, 6 \mathrm{H}) ;{ }^{13} \mathrm{C} \mathrm{NMR}$ $\left(101 \mathrm{MHz}, \mathrm{D}_{2} \mathrm{O}\right)_{\text {_ }} 176.6,176.2,84.1,80.1,79.5,76.0,75.4,74.1,72.3,71.6,70.7,69.5,65.6$, $63.9,63.6,62.8,61.5,35.9,35.7,18.1,18.0,12.9 ;{ }^{31} \mathrm{P}$ NMR $\left(162 \mathrm{MHz}, \mathrm{D}_{2} \mathrm{O}\right){ }_{-} 64.7,-0.25$. MALDI-HRMS $[\mathrm{M}+3 \mathrm{Na}]^{3+}$ calcd. for $\mathrm{C}_{17} \mathrm{H}_{33} \mathrm{O}_{16} \mathrm{P}_{2} \mathrm{SNa}_{3}, 656.0658$; found 656.0604 .

1D-O-(1,2-Di-O-oleoyl-sn-(2S)-glycerol-3-phospho)-5-(phosphothionate)-myo-inositol (4) was obtained from $\mathbf{1 7 b}$ as described for 3, yield 67\%. ${ }^{1} \mathrm{H}$ NMR (400 MHz, CD $\left.3 \mathrm{OD}\right)_{-} 5.32$ $(\mathrm{m}, 5 \mathrm{H}), 4.20-3.96(\mathrm{~m}, 3 \mathrm{H}), 3.82-3.71(\mathrm{~m}, 3 \mathrm{H}), 3.60-3.51(\mathrm{~m}, 2 \mathrm{H}), 3.42(\mathrm{~m}, 2 \mathrm{H}), 2.30(\mathrm{~m}, 4 \mathrm{H})$, $2.00(\mathrm{~m}, 8 \mathrm{H}), 1.59(\mathrm{~m}, 4 \mathrm{H}), 1.28(\mathrm{~m}, 40 \mathrm{H}), 0.88(\mathrm{~s}, 6 \mathrm{H}) ;{ }^{13} \mathrm{C} \mathrm{NMR}\left(101 \mathrm{MHz}, \mathrm{CD}_{3} \mathrm{OD}\right)_{-}$ 173.0, 172.7, 129.7, 129.6, 81.0, 79.5, 78.7, 76.9, 75.7, 75.2, 73.2, 72.1, 70.9, 68.2, 66.8, 66.2, 63.1, 61.7, 33.7, 31.8, 29.67, 29.59, 29.44, 29.28, 29.17, 29.08, 29.01, 28.97, 26.99, 26.95, 24.8, 22.5, 13.4; ${ }^{31} \mathrm{P}$ NMR (162 MHz, $\left.\mathrm{CD}_{3} \mathrm{OD}-\mathrm{CDCl}_{3}\right)_{-} 63.5,0.78$ (m). MALDI-HRMS [M $-\mathrm{H}+\mathrm{Na}]^{+}$calcd. for $\mathrm{C}_{45} \mathrm{H}_{83} \mathrm{O}_{15} \mathrm{P}_{2} \mathrm{SNa}$, 979.4753; found 979.4791.

\section{Liposome Binding Assay}

The liposome binding assays were performed as described ${ }^{43}$. Briefly, solutions of 1palmitoyl-2-oleoyl-sn-glycero-3-phosphocholine (DPPC), 1-palmitoyl-2-oleoyl-snglycero-3-phosphoethanolamine (DPPE), 1-palmitoyl-2-oleoyl-sn-glycero-3-phosphoserine (DPPS) (Avanti) containing either PtdIns, PtdIns(5)P, 5-MP PtdIns(5)P (2), 5-PT-PtdIns(5)P (4) or no phosphoinositide were dissolved in $\mathrm{CHCl}_{3}: \mathrm{MeOH}: \mathrm{H}_{2} \mathrm{O}$ (65:25:4) and dried down under vacuum. The lipids were resuspended in $800 \mu \mathrm{L} 20 \mathrm{mM}$ Tris, $100 \mathrm{mM} \mathrm{KCl}, \mathrm{pH} 7.3$ and sonicated using a bath sonicator for $15 \mathrm{~min}$ at $25^{\circ} \mathrm{C}$. Liposomes were collected by centrifugation at $25,000 \times \mathrm{g}$ for 30 minutes and finally resuspended in $95 \mu \mathrm{L}$ of buffer by vortexing and 
additional sonication for $3 \mathrm{~min}$. Liposomes were incubated with $5 \mu \mathrm{L}$ of $2 \mu \mathrm{g} / \mu \mathrm{L}$ GST-ING2 or GST for $1 \mathrm{~h}$ at $\mathrm{rt}$ and then collected again by centrifugation. The liposome pellets were separated from the supernatant and resuspended in $100 \mu \mathrm{L}$ of buffer. The pellet and supernatant fractions were analyzed by SDS-PAGE using Coomassie brilliant blue staining.

\section{HT1080 Cell Death Assay}

HT1080 cells were incubated with vehicle or $45 \mathrm{nM}$ neocarzinostatin (Sigma), at $16 \mathrm{~h}$ with 10 $\mu \mathrm{M}$ of either buffer, or dipalmitoyl PtdIns, dipalmitoyl PtdIns(5)P, dioleoyl 5-MP PtdIns(5)P (2), or dioleolyl 5-PT-PtdIns(5)P (4) were added and cells were incubated in the combined mixture for 12 additional hours. After incubation, dead cells were collected and added to the cells collected after trypsin treatment of the plates and total cells spun down. Cell death was measured by trypan blue exclusion following the manufacturer's protocol (Invitrogen).

\section{Molecular Modeling}

The sequence of human ING2 was submitted to the SWISS-MODEL Server (http://swissmodel.expasy.org/) in "first approach mode". The server provided five homologous templates in PDB bank 1wes, 1weu, 1wen, 2g6q, and 1x4i). Then made a sequence alignment by alignment module of MODELLER $8 \mathrm{v} 2$. Based on twenty models of 1x4i and other four templates, twenty homology models were built by MODELLER $8 \mathrm{v} 2$ in automodel mode. After reconstruction of the model side chains by iso-sterically replacing template side chains and energy minimization by the GROMOS96 force field, the models of ING2 C-terminal was obtain as a pdb file. AutoDock3.0 software package, with the graphical user interface AutoDockTools (ADT), was used to dock small molecules (PtdIns(5)P and analogues) to ING2 C-terminal domain. The zinc atoms in the active site were each manually assigned a charge of +2 and all other atom values were generated automatically by ADT. Using AutoGrid, a grid of $72 \AA \times 72 \AA \times 80 \AA$ with $0.375 \AA$ spacing was calculated around the docking area for relative ligand atom types of PtdIns(5)P and analogues. Separate docking computations were performed for each ligand using the Lamarckian Genetic Algorithm Local Search (GALS) method. The docking conformations of each ligand were clustered on the basis of root-meansquare deviation (rmsd) and ranked on the basis of free energy of binding. The top-ranked conformations were visually studied for good chemical geometry. Based on the complex of ING2-PtdIns(5)P, the binding interactions were determined by LIGPLOT 4.4.2 giving the hydrogen bonds and hydrophobic contacts information.

\section{Supplementary Material}

Refer to Web version on PubMed Central for supplementary material.

\section{Acknowledgements}

We thank the NIH (NS 29632 to G.D.P., GM 079641 to O.G., and GM 071424 and CA 113472 to T.G.K.). O.G. is a recipient of a Burroughs Wellcome CABS award and a Kimmel Scholar award. We also thank P. Neilsen (Echelon Biosciences, Inc.) for generous gifts of PtdIns(5)P and PtdIns.

\section{References}

1. Payrastre B, Missy K, Giuriato S, Bodin S, Plantavid M, Gratacap M. Cell Signal 2001;13:377-87. [PubMed: 11384836]

2. Prestwich GD. Chem Biol 2004;11:619-37. [PubMed: 15157873]

3. Clarke JH, Letcher AJ, D'Santos CS, Halstead JR, Irvine RF, Divecha N. Biochem J 2001;357:90510. [PubMed: 11463365]

4. Jones DR, Divecha N. Curr Opin Genet Dev 2004;14:196-202. [PubMed: 15196467] 
5. Alvarez-Venegas R, Sadder M, Hlavacka A, Baluska F, Xia Y, Lu G, Firsov A, Sarath G, Moriyama H, Dubrovsky J, Avramova Z. Proc Natl Acad Sci USA 2006;103:6049-6054. [PubMed: 16585509]

6. Gozani O, Karuman P, Jones DR, Ivanov D, Cha J, Lugovskoy AA, Baird CL, Zhu H, Field SJ, Lessnick SL, Villasenor J, Mehrotra B, Chen J, Rao VR, Brugge JS, Ferguson CG, Payrastre B, Myszka DG, Cantley LC, Wagner G, Divecha N, Prestwich GD, Yuan J. Cell 2003;114:99-111. [PubMed: 12859901]

7. Brunecky R, Lee S, Rzepecki PW, Overduin M, Prestwich GD, Kutateladze AG, Kutateladze TG. Biochemistry 2005;44:16064-71. [PubMed: 16331966]

8. Feng X, Hara Y, Riabowol K. Trends Cell Biol 2002;12:532-8. [PubMed: 12446115]

9. Garkavtsev I, Grigorian IA, Ossovskaya VS, Chernov MV, Chumakov PM, Gudkov AV. Nature 1998;391:295-8. [PubMed: 9440695]

10. Nagashima M, Shiseki M, Miura K, Hagiwara K, Linke SP, Pedeux R, Wang XW, Yokota J, Riabowol K, Harris CC. Proc Natl Acad Sci USA 2001;98:9671-6. [PubMed: 11481424]

11. Shi X, Gozani O. J Cell Biochem 2005;96:1127-36. [PubMed: 16167330]

12. Pena PV, Davrazou F, Shi X, Walter KL, Verkhusha VV, Gozani O, Zhao R, Kutateladze TG. Nature 2006;442:100-103. [PubMed: 16728977]

13. Kaadige MR, Ayer KE. J Biol Chem 2006;281:28831-28836. [PubMed: 16893883]

14. Whiteford CC, Brearley CA, Ulug ET. Biochem J 1997;323(Pt 3):597-601. [PubMed: 9169590]

15. Peng J, Prestwich GD. Tetrahedron Lett 1998;39:3965-3968.

16. Xu Y, Lee SA, Kutateladze TG, Sbrissa D, Shisheva A, Prestwich GD. J Am Chem Soc 2006;128:885897. [PubMed: 16417379]

17. Gajewiak J, Xu Y, Lee SA, Kutateladze TG, Prestwich GD. Org Lett 2006;8:2811-2813. [PubMed: 16774263]

18. Zhang H, Xu Y, Zhang Z, Liman ER, Prestwich GD. J Am Chem Soc 2006;128:5642-5643. [PubMed: 16637624]

19. Zhang H, Markadieu N, Beawens R, Erneux C, Prestwich GD. J Am Chem Soc 2006;128:1646416465. [PubMed: 17177371]

20. Prestwich GD, Xu Y, Qian L, Gajewiak J, Jiang G. Biochem Soc Trans 2005;33:1357-1361. [PubMed: 16246118]

21. Kubiak RJ, Bruzik KS. J Org Chem 2003;68:960-968. [PubMed: 12558421]

22. Lindberg J, Ohberg L, Garegg PJ, Konradsson P. Tetrahedron 2002;58:1387-1398.

23. Pietrusiewicz KM, Salamonczyk GM, Bruzik KS. Tetrahedron 1992;48:5523-5542.

24. Bruzik KS, Tsai M. J Am Chem Soc 1992;114:6361-6374.

25. Jeanmaire T, Hervaud Y, Boutevin B. Phosphorus, Sulfur and Silicon 2002;177:1137-1145.

26. Xu Y, Flavin MT, Xu ZQ. J Org Chem 1996;61:7697-7701. [PubMed: 11667723]

27. Kulagowski JJ, Baker R, Fletcher SR. J Chem Soc Chem Commun 1991:1649-1650.

28. Chen J, Profit AA, Prestwich GD. J Org Chem 1996;61:6305-6312. [PubMed: 11667472]

29. Heeb NV, Nambiar KP. Tetrahedron Lett 1993;34:6193-6196.

30. Jones D, Bultsma Y, Kuene WJ, Halstead J, Elouarrat D, Mohammed S, Heck A, D'Santos C, Divecha N. Molec Cell 2006;23:685-695. [PubMed: 16949365]

31. Sali A, Blundell TL. J Mol Biol 1993;234:779-815. [PubMed: 8254673]

32. Marti-Renom MA, Stuart A, Fiser A, Sanchez R, Melo F, Sali A. Annu Rev Biophys Biomol Struct 2000;29:291-325. [PubMed: 10940251]

33. Fiser A, Do RK, Sali A. Protein Science 2000;9:1753-1773. [PubMed: 11045621]

34. Goodsell DS, Olson AJ. Proteins 1990;8:195-202. [PubMed: 2281083]

35. Morris GM, Goodsell DS, Huey R, Olson AJ. J Comput Aided Mol Des 1996;10:293-304. [PubMed: 8877701]

36. Morris GM, Goodsell DS, Halliday RS, Huey REHW, Belew RK, Olson AJ. J Comp Chem 1998;19:1639-1662.

37. Wallace AC, Laskowski RA, Thornton JM. Protein Eng 1995;8:127-34. [PubMed: 7630882] 
38. Wagner MJ, Gogela-Spehar M, Skirrow RC, Johnston RN, Riabowol K, Helbing CC. J Biol Chem 2001;276:47013-20. [PubMed: 11600495]

39. Schwede T, Kopp J, Guex N, Peitsch MC. Nucleic Acids Res 2003;31:3381-5. [PubMed: 12824332]

40. Kopp J, Schwede T. Nucleic Acids Res 2004;32:D230-4. [PubMed: 14681401]

41. Guex N, Peitsch MC. Electrophoresis 1997;18:2714-23. [PubMed: 9504803]

42. Westbrook J, Feng Z, Chen L, Yang H, Berman HM. Nucleic Acids Res 2003;31:489-91. [PubMed: 12520059]

43. Lee SA, Eyeson R, Cheever ML, Geng J, Verkhusha VV, Burd C, Overduin M, Kutateladze TG. Proc Natl Acad Sci USA 2005;102:13052-13057. [PubMed: 16141328] 


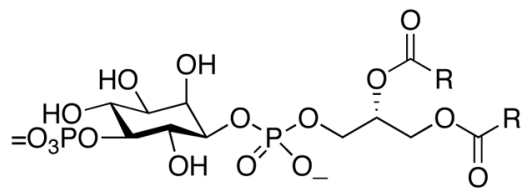

Ptdlns(5)P

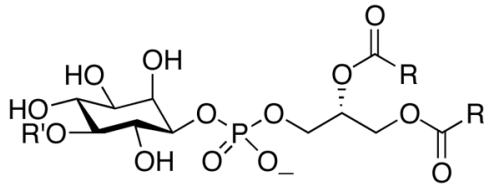

$1, \mathrm{R}=\mathrm{C}_{3} \mathrm{H}_{7}, \mathrm{R}^{\prime}=\mathrm{CH}_{2} \mathrm{PO}_{3}{ }^{2-}$

2, R $=\mathrm{C}_{17} \mathrm{H}_{33}, \mathrm{R}^{\prime}=\mathrm{CH}_{2} \mathrm{PO}_{3}{ }^{2-}$

$3, \mathrm{R}=\mathrm{C}_{3} \mathrm{H}_{7}, \mathrm{R}^{\prime}=\mathrm{P}(\mathrm{S}) \mathrm{O}_{2}{ }^{2-}$

$4, \mathrm{R}=\mathrm{C}_{17} \mathrm{H}_{33}, \mathrm{R}^{\prime}=\mathrm{P}(\mathrm{S}) \mathrm{O}_{2}{ }^{2-}$

Figure 1.

5-Methylenephosphonate and 5-Phosphothionate Analogues of PtdIns(5)P 


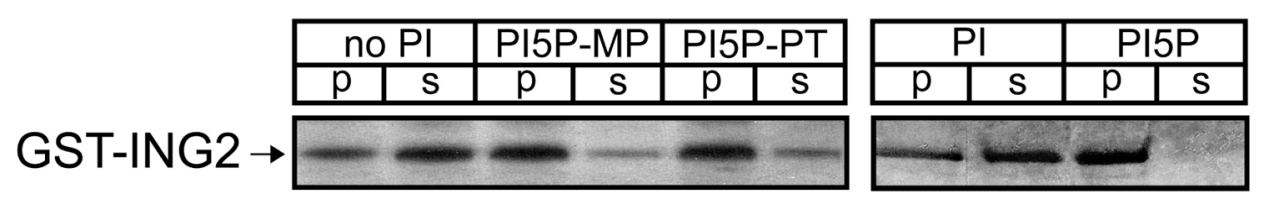

Figure 2.

PtdIns(5)P analogues are efficiently recognized by ING2. The SDS-PAGE gels showing the partitioning of the GST-fused C-terminal tail of ING2 between the supernatant fraction (S) and the liposome pellet $(\mathrm{P})$. To better mimic native membranes, liposomes were prepared from phospholipids typically found in bilayers including PtdCho, PtdEtn, PtdSer in a ratio (65:26:9) or PtdCho, PtdEtn, PtdSer and the corresponding phosphoinositide in a ratio (54:22:9:15). 


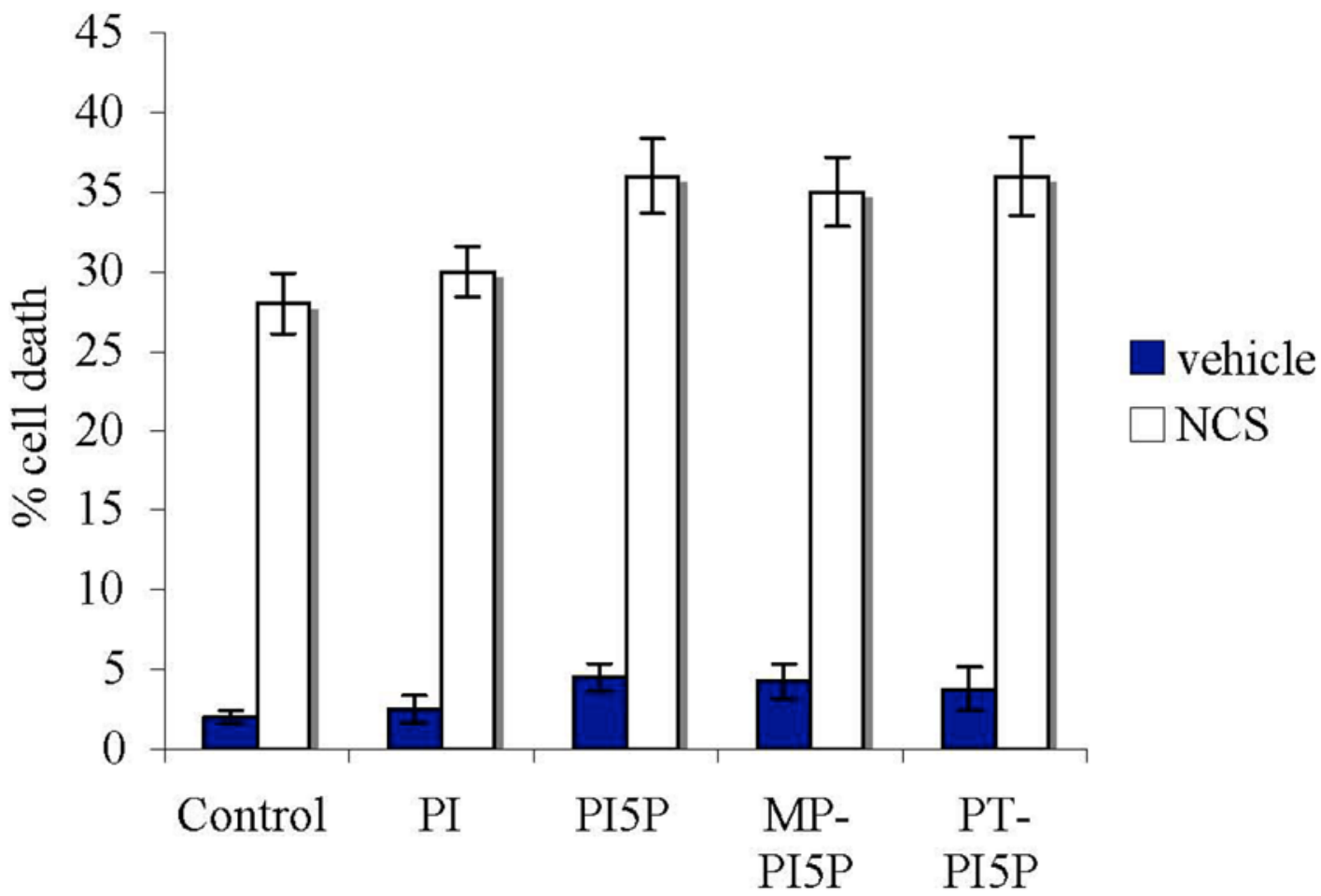

Figure 3.

PtdIns(5)P and Analogues Augment Cell Death Induced by neocarzinostatin (NCS) Treatment. Cell death was measured in HT1080 cells treated with $10 \mu \mathrm{M}$ of the indicated lipid or no lipid control, $\pm 45 \mathrm{nM}$ NCS. The error bars represent the mean \pm s.e.m. for four experiments. 
1UES:-SGEFAIDPNEPIYCLCNQUSYGEMI GCDNEQCPIEUFHFSCUSL TYKPKGKWYCPKCRGDSGPSSG

A

1Wen :---DMPUDPNEPIYCLCHQUSYGEMI GCDNPDCS IEUFHFACUGLTIKPRGKWFCPRCSQESGPSSG--

1WeU:------NEPIYCLCHQUSYGEHI GCDNPDCS IEUFHF ACUGLITKPRGKUFCPRCSQESGPSSG

1X4i:----GSSGSSGYCI I NQUSYGEHUGCDNQDCP IEUFHYGCUGL TEAPKGKWYCPQCTAAH-KRRG-SRHKSGP--SSG

2g6q: -EPTYCLCNQUSYGEHI GCDNEQCP IEUFHFSCUSLTYKPKGKWYCPKCRGDN-

ING2: SPUEFAIDPNEPTYCLCNQUSYGEMI GCDNEQCP IEUFHF SCUSLTYKPKGKUYCPKCRGDNEKTHDKSTEKTKKDRRSR

*

*

$* * * * * *$

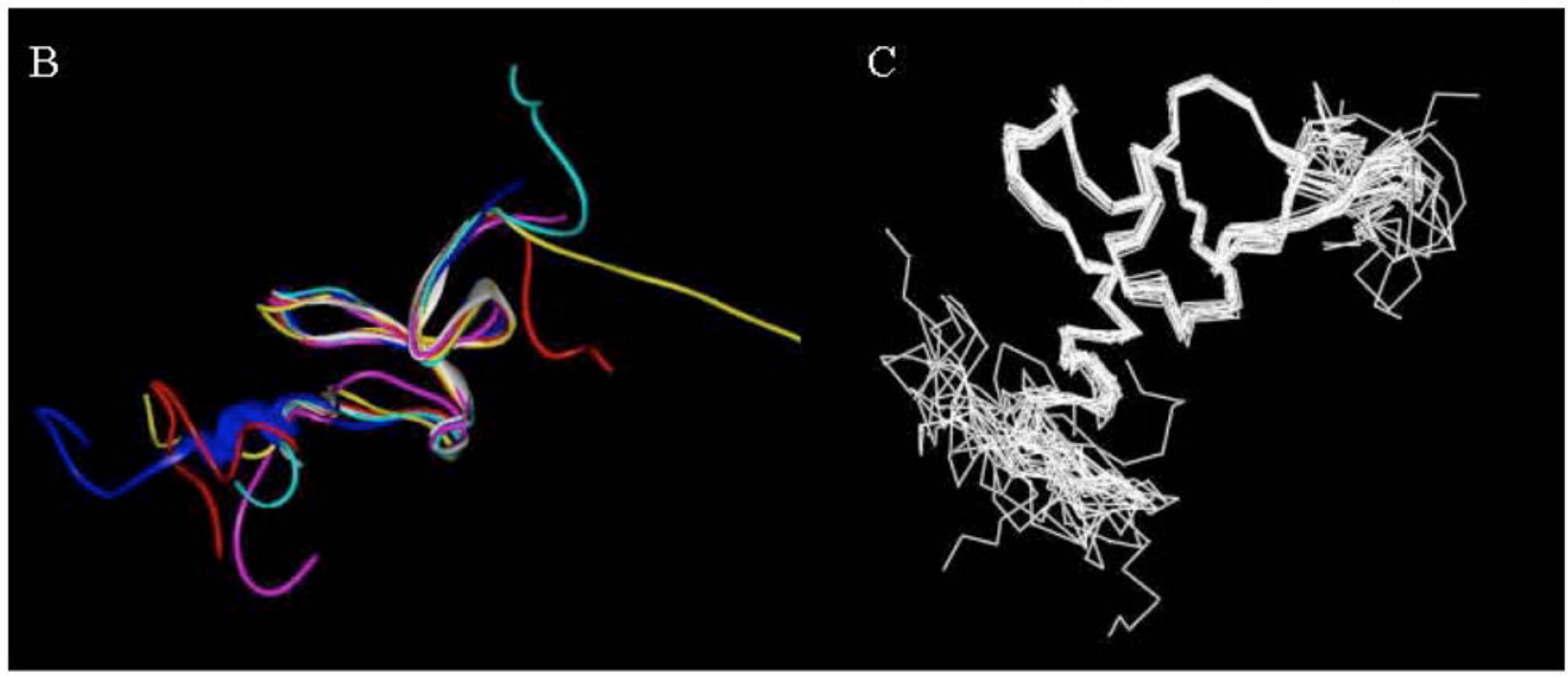

Figure 4.

(Panel A) Sequence Alignment of ING2 (202-281) with Related Family Members from PDB. The alignment was performed under the module of ALIGNMENT in MODELLER. (Panel B) Structural alignment of ING2 model (one of twenty models, red), $\mathbf{2 g 6 q}$ (white), 1x4i (blue), 1weu (purple), 1wes (cyan), and 1wen (yellow). PHD domains are the conserved fractions in the center of structures, end with a short helix and the following tails on left side are polybasic regions. (Panel C) Twenty ING2 models built by MODELLER. The multi-orientation coils on left side are polybasic C-termini. 


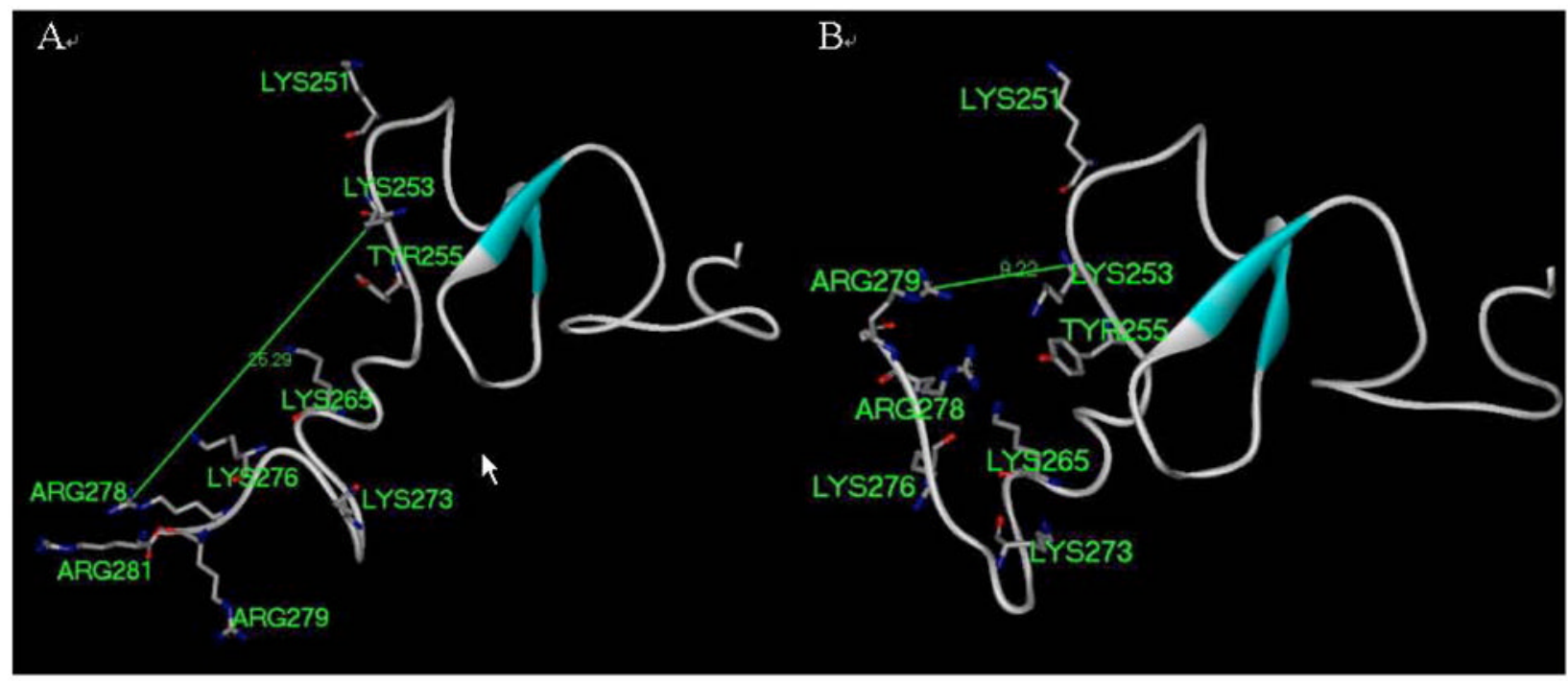

Figure 5.

Structural analysis of two representative models from 20 models generated by homology modeling. Panel A. Model 1. Panel B. Model 2. 


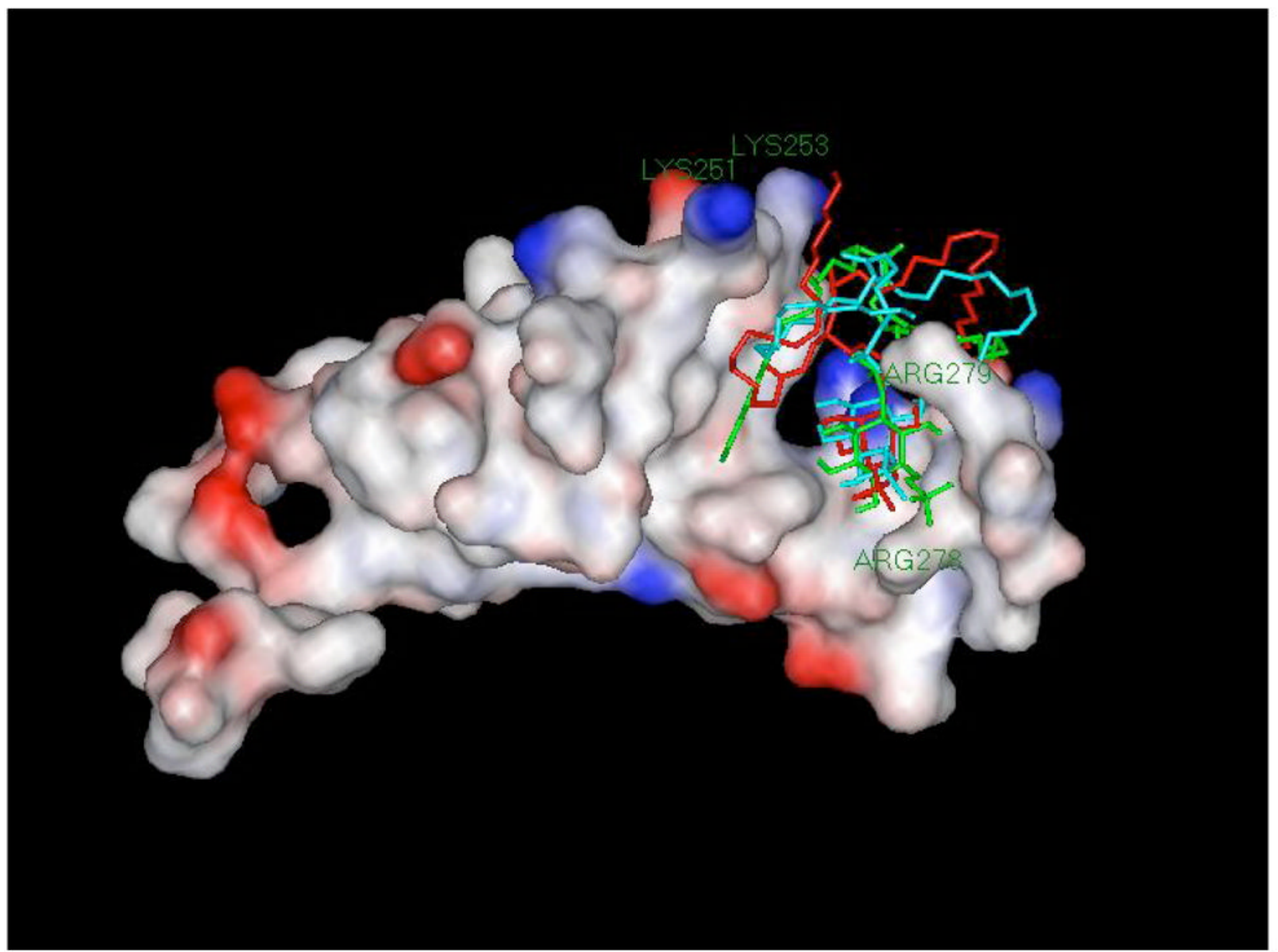

Figure 6.

Docking conformations of $\mathrm{diC}_{18: 1}$-PtdIns(5)P(red), $\operatorname{diC}_{18: 1}$-MP-PtdIns(5)P (2, green) and $\mathrm{diC}_{18: 1}$-PT-PtdIns(5)P (4, cyan) in surface of ING2 C-terminal model. 


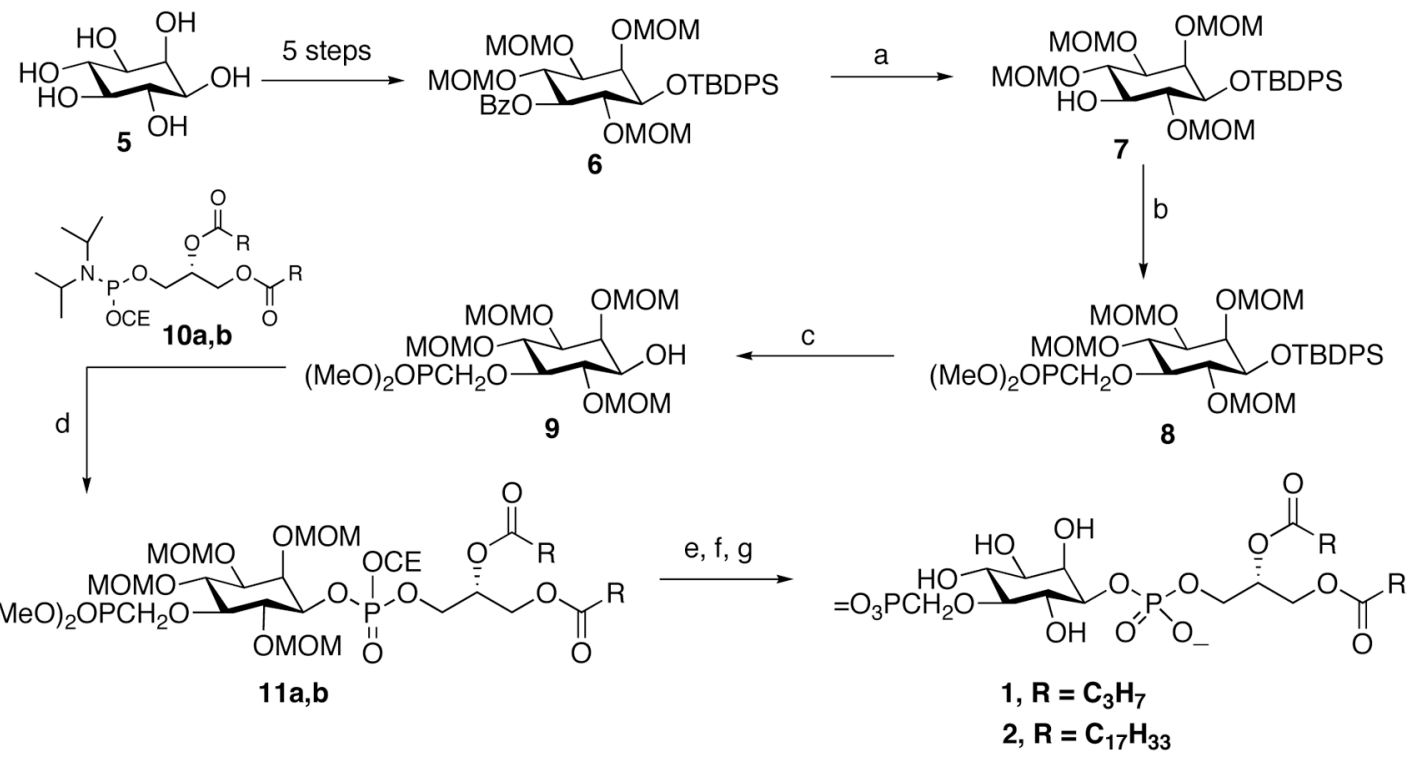

Scheme 1.

Synthesis of 5-Methylenephosphonate Analogues of PtdIns(5) P. Reagents and conditions: (a) $\mathrm{NaOMe}, \mathrm{MeOH}$, r.t., 24 h; (b) dimethyl phosphonomethyltriflate, $\mathrm{NaH}$, THF, $0{ }^{\circ} \mathrm{C}$ then r.t., $12 \mathrm{~h}$; (c) TBAF_3 $\mathrm{H}_{2} \mathrm{O}$, THF, r.t., $4 \mathrm{~h}$; (d) $1 H$-tetrazole, $\mathrm{CH}_{2} \mathrm{Cl}_{2}$, Ar, r.t., 24 h; then $t$-BuOOH, 1 h; (e) TEA, BSTFA, MeCN, Ar, r.t., 24 h; (f) TMSBr, BSTFA, Ar, r.t., 10 h; (g) MeOH, r.t., $1 \mathrm{~h}$. 


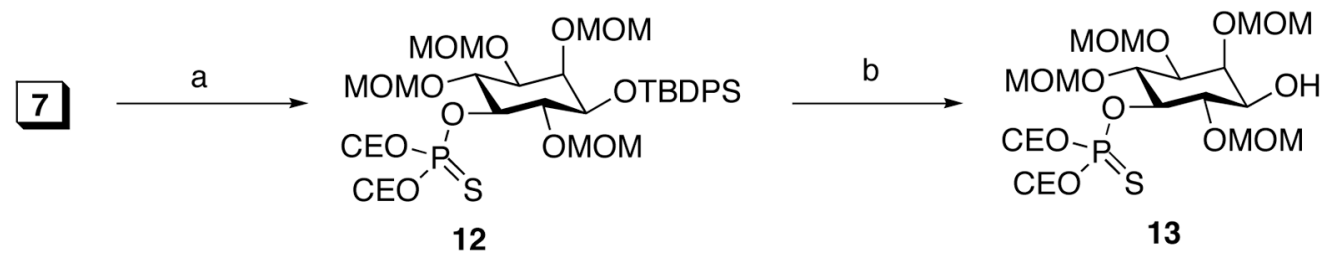

Scheme 2.

Synthesis of Intermediate 13. Reagents and conditions: (a) bis(2-cyanoethyl) diisopropylphosphorodiamidite, $1 H$-tetrazole, $\mathrm{MeCN}, \mathrm{Ar}$, r.t., 2 h; then sulfur, $\mathrm{CS}_{2} / \mathrm{Py}(1: 1)$, r.t., 3 h; (b) HF-Py, THF, r.t., 3 weeks. 


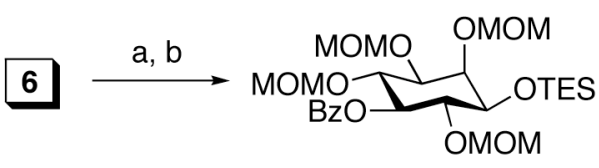

14

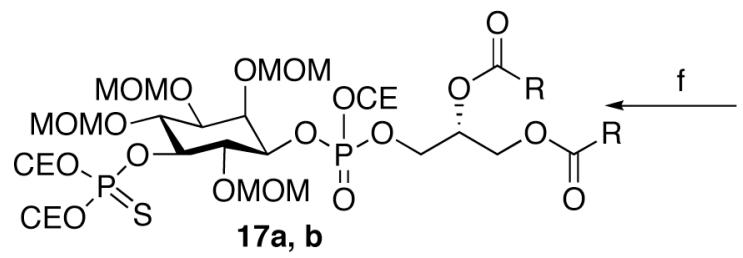

$17 a, b$<smiles>[R]C(=O)OC[C@H](COP(=O)([O-])OC1C(O)C(O)C(OP([O-])([O-])=S)C(O)(O)C1O)OC([R])=O</smiles>

3, $\mathrm{R}=\mathrm{C}_{3} \mathrm{H}_{7}$

$4, \mathrm{R}=\mathrm{C}_{17} \mathrm{H}_{33}$
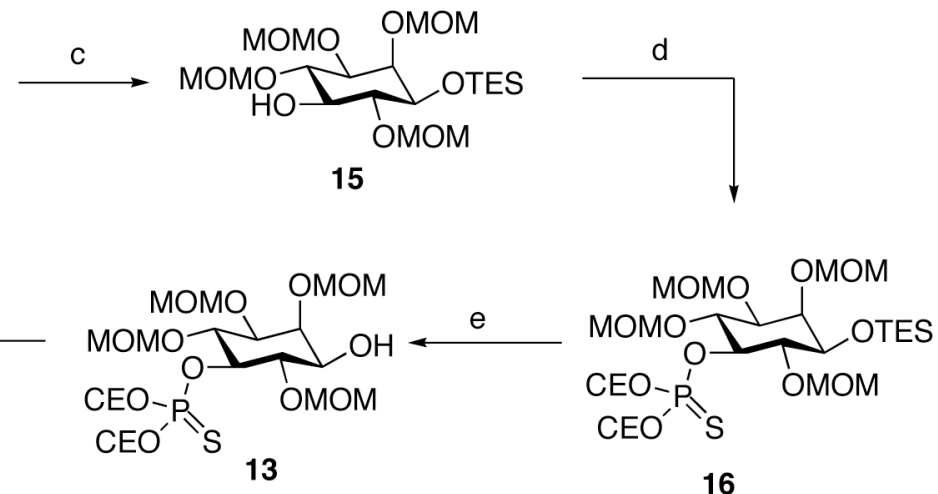

\section{Scheme 3.}

Synthesis of 5-Phosphothionate Analogues of PtdIns(5)P. Reagents and conditions: (a) TBAF_3 $\mathrm{H}_{2} \mathrm{O}$, DMF, r.t., 6 h; (b) triethylsilyl chloride, imidazole, $\mathrm{CH}_{2} \mathrm{Cl}_{2}$, r.t., 15 h; (c) DIBAL-H, $\mathrm{CH}_{2} \mathrm{Cl}_{2},-78^{\circ} \mathrm{C}, 2 \mathrm{~h}$; (d) bis(2-cyanoethyl)diisopropylphosphorodiamidite, $1 H$ tetrazole, $\mathrm{MeCN}$, Ar, r.t., 2 h; then sulfur, $\mathrm{CS}_{2} / \mathrm{Py}(1: 1)$, r.t., 6 h; (e) $\mathrm{NH}_{4} \mathrm{~F}, \mathrm{MeOH}$, r.t., 20 h; (f) 10a (or 10b), $1 H$-tetrazole, $\mathrm{CH}_{2} \mathrm{Cl}_{2}$, Ar, r.t., $24 \mathrm{~h}$; then $t$-BuOOH, $1 \mathrm{~h}$; (g) TEA, BSTFA, $\mathrm{MeCN}$, Ar, r.t., 24 h; (h) TMSBr, BSTFA, Ar, r.t., 2 h; (i) MeOH, r.t., 1 h. 